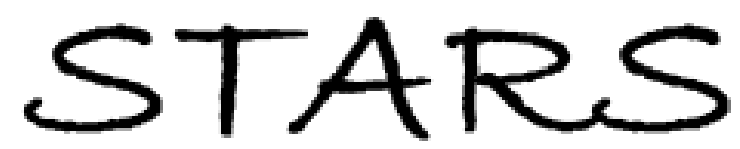

University of Central Florida

STARS

9-1-2016

\title{
Evaluation Of The Impact Of Slab Foundation Heat Transfer On Heating And Cooling In Florida
}

Florida Solar Energy Center

Danny Parker

Florida Solar Energy Center, dparker@fsec.ucf.edu

Part of the Energy Systems Commons

Find similar works at: https://stars.library.ucf.edu/fsec

University of Central Florida Libraries http://library.ucf.edu

This Contract Report is brought to you for free and open access by STARS. It has been accepted for inclusion in FSEC Energy Research Center ${ }^{\circledR}$ by an authorized administrator of STARS. For more information, please contact

STARS@ucf.edu.

\section{STARS Citation}

Florida Solar Energy Center and Parker, Danny, "Evaluation Of The Impact Of Slab Foundation Heat Transfer On Heating And Cooling In Florida" (2016). FSEC Energy Research Center ${ }^{\circledR} .110$.

https://stars.library.ucf.edu/fsec/110

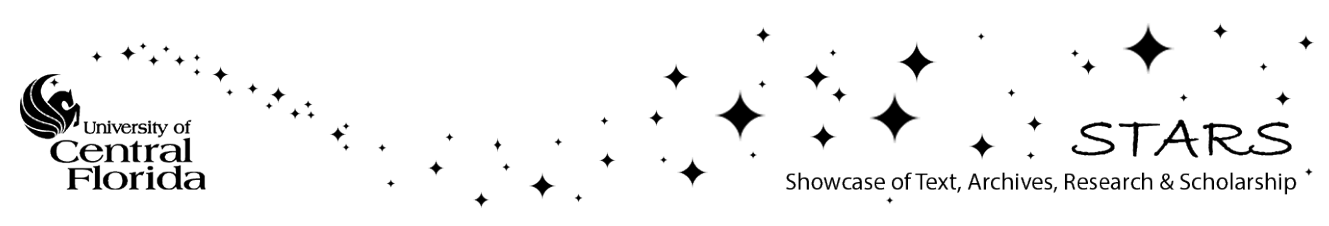




\title{
FLORIDA SOLAR ENERGY CENTER \\ Creating Energy Independence
}

\section{Evaluation of the Impact of Slab Foundation Heat Transfer on Heating and Cooling in Florida}

\author{
FSEC-CR-2042-16
}

Final Report

September 2016

\section{Authors}

Danny Parker

Jamie Kono

Robin Vieira

Lixing Gu

(C)2016 University of Central Florida.

All Rights Reserved.

1679 Clearlake Road

Cocoa, Florida 32922, USA

(321) 638-1000

www.floridaenergycenter.org 


\section{Disclaimer}

The Florida Solar Energy Center/University of Central Florida nor any agency thereof, nor any of their employees, makes any warranty, express or implied, or assumes any legal liability or responsibility for the accuracy, completeness, or usefulness of any information, apparatus, product, or process disclosed, or represents that its use would not infringe privately owned rights. Reference herein to any specific commercial product, process, or service by trade name, trademark, manufacturer, or otherwise does not necessarily constitute or imply its endorsement, recommendation, or favoring by the Florida Solar Energy Center/University of Central Florida or any agency thereof. The views and opinions of authors expressed herein do not necessarily state or reflect those of the Florida Solar Energy Center/University of Central Florida or any agency thereof. 


\section{Evaluation of the Impact of Slab Foundation Heat Transfer on Heating and Cooling in Florida}

D. Parker, J. Kono, R. Vieira, and L. Gu BA-PIRC

September 2016 


\section{NOTICE}

This report was prepared as an account of work sponsored by an agency of the United States government. Neither the United States government nor any agency thereof, nor any of their employees, subcontractors, or affiliated partners makes any warranty, express or implied, or assumes any legal liability or responsibility for the accuracy, completeness, or usefulness of any information, apparatus, product, or process disclosed, or represents that its use would not infringe privately owned rights. Reference herein to any specific commercial product, process, or service by trade name, trademark, manufacturer, or otherwise does not necessarily constitute or imply its endorsement, recommendation, or favoring by the United States government or any agency thereof. The views and opinions of authors expressed herein do not necessarily state or reflect those of the United States government or any agency thereof.

Available electronically at SciTech Connect http:/www.osti.gov/scitech

Available for a processing fee to U.S. Department of Energy

and its contractors, in paper, from:

U.S. Department of Energy

Office of Scientific and Technical Information

P.O. Box 62

Oak Ridge, TN 37831-0062

OSTI http://www.osti.gov

Phone: 865.576.8401

Fax: 865.576.5728

Email: reports@osti.gov

Available for sale to the public, in paper, from:

U.S. Department of Commerce

National Technical Information Service

5301 Shawnee Road

Alexandria, VA 22312

NTIS http://www.ntis.gov

Phone: 800.553 .6847 or 703.605 .6000

Fax: 703.605.6900

Email: orders@ntis.gov 


\title{
Evaluation of the Impact of Slab Foundation Heat Transfer on Heating and Cooling in Florida
}

\author{
Prepared for: \\ The National Renewable Energy Laboratory \\ On behalf of the U.S. Department of Energy's Building America Program \\ Office of Energy Efficiency and Renewable Energy \\ 15013 Denver West Parkway \\ Golden, CO 80401 \\ NREL Contract No. DE-AC36-08GO28308 \\ Prepared by: \\ D. Parker, J. Kono, R. Vieira, and L. Gu \\ Building America Partnership for Improved Residential Construction \\ 1679 Clearlake Rd. \\ Cocoa, FL \\ NREL Technical Monitor: Stacey Rothgeb \\ Prepared under Subcontract No. KNDJ-0-40339-05
}

September 2016 
The work presented in this report does not represent performance of any product relative to regulated minimum efficiency requirements.

The laboratory and/or field sites used for this work are not certified rating test facilities. The conditions and methods under which products were characterized for this work differ from standard rating conditions, as described.

Because the methods and conditions differ, the reported results are not comparable to rated product performance and should only be used to estimate performance under the measured conditions. 


\section{Contents}

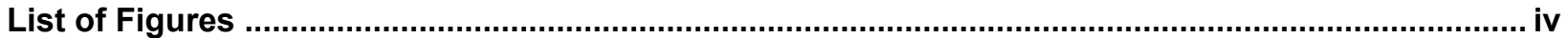

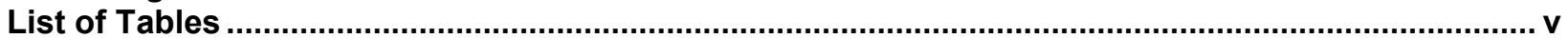

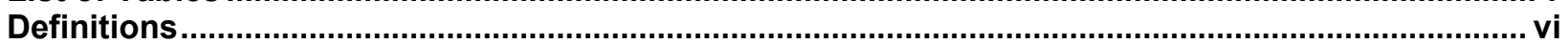

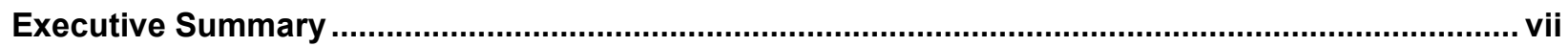

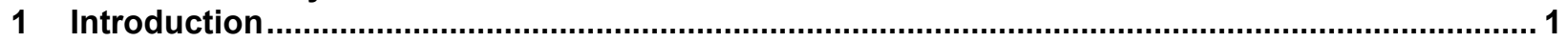

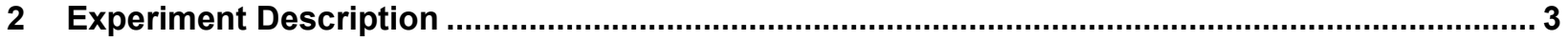

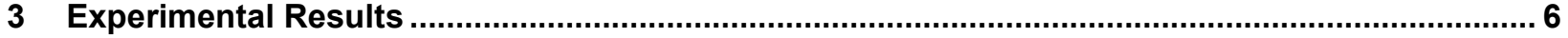

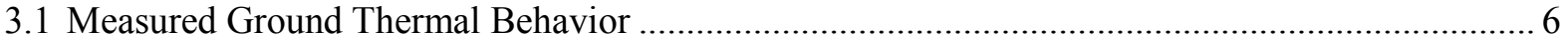

3.2 Measured and Estimated Soil Thermal Properties ..................................................................... 7

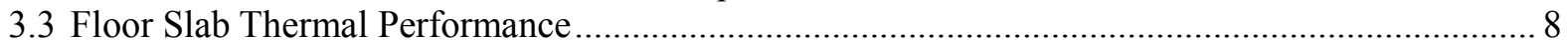

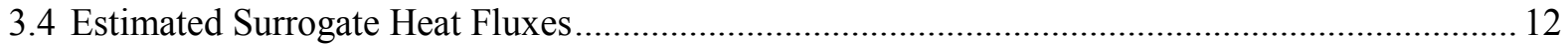

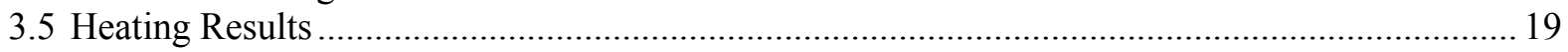

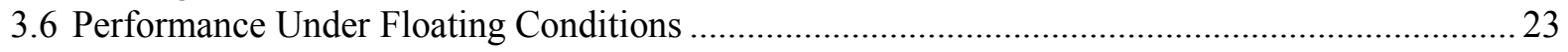

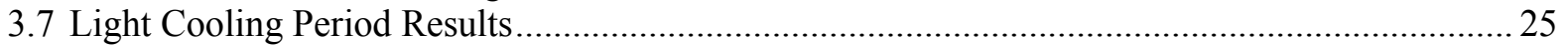

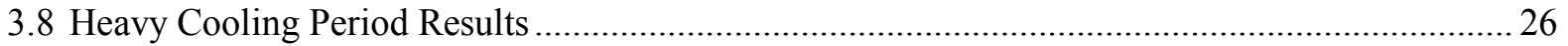

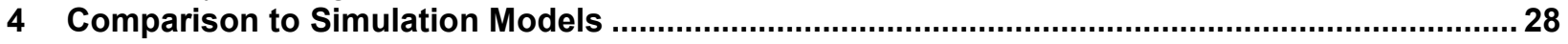

4.1 Sensitivity to Soil Temperature Assumptions in BEopt .......................................................... 30

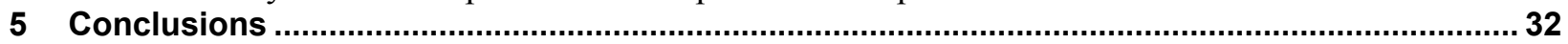

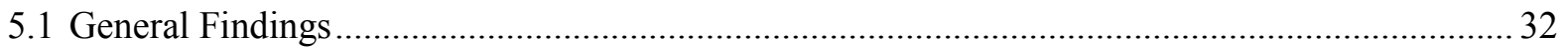

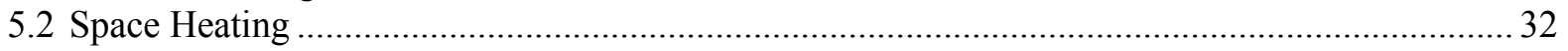

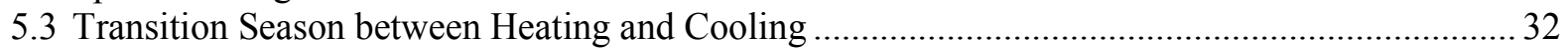

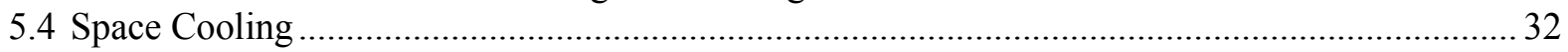

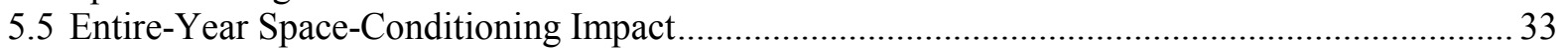

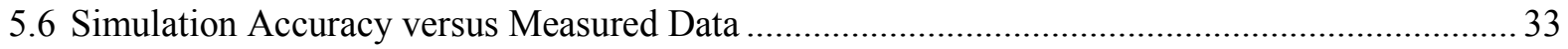

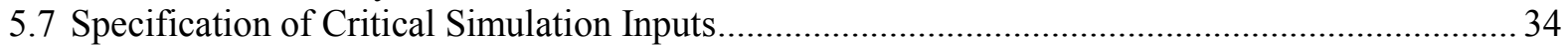

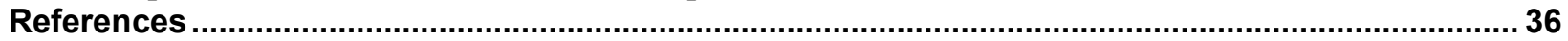

Appendix. Kusuda's Procedure To Estimate Soil Thermal Diffusivity ............................................... 38 


\section{List of Figures}

Figure 1. Percentage of new U.S. homes by foundation type. Image created from U.S. Department of Census data.

Figure 2. Side-by-side FRTF buildings at the FSEC Cocoa, Florida ................................................ 3

Figure 3. Schematic diagram of slab temperature measurement points at FRTF........................... 4

Figure 4. Measured daily average temperatures: July 9, 2014, to July 9, 2015, at varying depths versus ambient air temperature.

Figure 5. Center slab daily temperature profiles for July 9, 2014, to July 9, 2015, for the carpeted east building.

Figure 6. Center slab daily temperature profiles for July 9,2014 , to July 9,2015 , for the concretefloored west building

Figure 7. Comparison between the carpeted east building and uncarpeted west building .............. 11

Figure 8. Slab surface temperature locations .............................................................................. 12

Figure 9. North edge surrogate heat fluxes $(\Delta T)$ : Green (west exposed), brown (east carpeted) .... 13

Figure 10. North midpoint surrogate fluxes $(\Delta T)$ : Green (west exposed), brown (east carpeted) ... 13

Figure 11. Slab floor center surrogate fluxes $(\Delta T)$ : Green (west exposed), brown (east carpeted). 14

Figure 12. East edge surrogate fluxes $(\Delta T)$ : Green (west exposed), brown (east carpeted) ............. 14

Figure 13. West edge surrogate fluxes $(\Delta T)$ : Green (west exposed), brown (east carpeted) ............ 15

Figure 14. East midpoint surrogate fluxes $(\Delta T)$ : Green (west exposed), brown (east carpeted) ..... 15

Figure 15. South edge surrogate fluxes $(\Delta T)$ : Green (west exposed), brown (east carpeted).......... 16

Figure 16. West midpoint surrogate fluxes $(\Delta T)$ : Green (west exposed), brown (east carpeted) .... 16

Figure 17. South midpoint surrogate fluxes $(\Delta T)$ : Green (west exposed), brown (east carpeted)... 17

Figure 18. Slab surface temperature locations ......................................................................... 17

Figure 19. Contours of slab \& ground thermal performance during peak winter day: Feb 20, 2015.

Note the end points of the contour plots are actually 32.5 feet from end of the structures and

have been shortened to simplify display.

Figure 20. Setup for time lapse thermography of uncovered west building slab floor on the coldest night of 2013.

Figure 21. Time lapse thermography of southwest slab floor on west building interior on February 17,2013 . Note edge losses are clearly apparent by dark blue regions during evening hours. . 23

Figure 22. Interior temperatures while floating during a period of warm spring weather, March 1324,2015

Figure 23. Contours during spring floating condition: Mar 13-24, 2015. Note the end points of the contour plots are actually $\mathbf{3 2 . 5}$ feet from end of the structures and have been shortened to simplify display.

Figure 24. Contours during a light cooling period: October 19-30, 2014. Note the end points of the contour plots are actually $\mathbf{3 2 . 5}$ feet from end of the structures and have been shortened to simplify display.

Figure 25. Contours during an extended period of heavy cooling: June 13-28th, 2015. Note the end points of the contour plots are actually $\mathbf{3 2 . 5}$ feet from end of the structures and have been

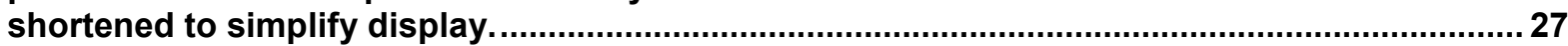

Figure 26. FRTF geometry input into BEopt with EnergyPlus ....................................................... 29

Figure 27. Simulated results for no-carpet (Point 1) versus carpet (Point 2) in FRTF with BEopt and EnergyPlus.

Figure 28. Map of average annual temperature in the continental United States. Image from the National Oceanic and Atmospheric Administration 


\section{List of Tables}

Table 1. Summary of Experimental Measurements ..................................................................... 5

Table 2. Monthly Undisturbed Ground Temperature at FRTF: July 1, 2014, to July 1, 2015............ 7

Table 3. Estimated Soil Thermal Diffusivity Using the First Order Harmonic Approach ................... 8

Table 4. Monthly Ground Temperature Under the Carpeted East Building at FRTF Experiment:

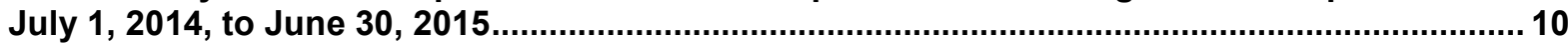

Table 5. Monthly Ground Temperature Under the Uncarpeted West Building at FRTF Experiment: July 1, 2014, to June 30, 2015.

Table 6. Monthly Surrogate Heat Flux Data $\Delta T\left({ }^{\circ} \mathrm{F}\right)$

Table 7. Interior Conditions and Space Heating Energy Use for the 14 Days of Heating Below $55^{\circ} \mathrm{F}$

Table 8. Interior Conditions and Space Heating Energy Use during the 4 Days of Heating Below $50^{\circ} \mathrm{F}$

Table 9. Interior Conditions and Space Heating Energy Use for Peak Heating Day, February 20, 2015

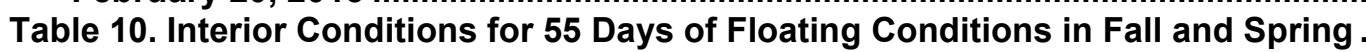

Table 11. Interior Conditions and Space Cooling Energy Use during 132 Days of Light Cooling

Table 12. Interior Conditions and Space Cooling Energy Use during the 115 Days of Heavy Cooling

Table 13. Interior Conditions and Space Cooling Energy Use during an Extended Heavy Cooling Period, June 13-28, 2015. 


\section{Definitions}

AHU

BA-PIRC

BEopt

Btu

DOE

DP

FRTF

FSEC

HVAC

RH

RMSE

SEER

TMY3

USCS
Air Handling Unit

Building America Partnership for Improved Residential Construction

Building Energy Optimization Software

British thermal unit

U.S. Department of Energy

Dew Point

Flexible Residential Test Facility

Florida Solar Energy Center

Heating, Ventilating, and Air Conditioning

Relative Humidity

Root-Mean-Square Error

Seasonal Energy Efficiency Ratio

Typical Meteorological Year 3 Data Set

Unified Soil Classification System 


\section{Executive Summary}

During the last three decades of energy-efficiency research, there has been limited study of heat transfer to slab-on-grade foundations in cooling-dominated climates. Most experimental research has focused on the impact of slab-on-grade foundations and insulation schemes on heat losses in heating-dominated climates. This is surprising because the floor area in single-family homes is generally equal to wall area, window area, or attic area, all of which have been extensively evaluated for heat-transfer properties. Moreover, slab foundations are the most common foundation type in cooling-dominated climates.

Slab-on-grade construction is very popular in southern states, accounting for $77 \%$ of new home floors according to 2014 U.S. Census data ${ }^{1}$. There is a widespread perception that tile flooring, as opposed to carpet, provides a cooler home interior in warm climates. Empirical research is needed because building energy simulation software programs running DOE-2 and EnergyPlus engines often rely on simplified models to evaluate the influence of flooring on interior temperature, even though in some cases more detailed models exist.

The U.S. Department of Energy Building America Partnership for Improved Residential Construction (BA-PIRC) performed experiments in the Florida Solar Energy Center's Flexible Residential Test Facility intended to assess for the first time (1) how slab-on-grade construction influences interior cooling in a cooling-dominated climate and (2) how the difference in a carpeted versus uncarpeted building might influence heating and cooling energy use. Two nominally identical side-by-side residential buildings were evaluated during the course of 1 year, from 2014 to 2015: the east building with a pad and carpet floor and the west building with a bare slab floor. A detailed grid shows temperature measurements taken on the slab surface at various locations as well as at depths of $1.0 \mathrm{ft}, 2 \mathrm{ft}, 5.0 \mathrm{ft}, 10.0 \mathrm{ft}$, and $20.0 \mathrm{ft}$ below the surface. Temperature measurements were taken at both buildings for more than 3 years prior to the experiments to ensure that the ground and foundation temperatures had fully come into equilibrium.

The average monthly undisturbed deep-ground temperature in central Florida, measured $32.5 \mathrm{ft}$ away from the buildings at a $20-\mathrm{ft}$ depth, varies by only a few degrees, from $77^{\circ} \mathrm{F}$ to $78^{\circ} \mathrm{F}$, during the course of 1 year. Deep-ground temperature is out of phase with the outdoor air temperature, the minimum point coming in spring and the maximum in late autumn. However, the nearness of the deep-ground temperature to the desired indoor cooling temperature makes increased foundation-to-earth contact unlikely to provide significant summer-season energy benefits. Collected data show highly visible heat flows in the slab floor and the layers of soil beneath it based on the observed profile of temperatures varying with depth. The observed behavior reflects the heat conductance as well as the capacitance and diffusivity of the soils: the temperature of each lower segment is strongly impacted by the successive temperatures above it, although it is increasingly out of phase with depth. The west building with the uncovered floor showed slightly greater amplitude in temperature variation in the ground temperatures under the slab during the course of 1 year.

\footnotetext{
${ }^{1}$ U.S. Census Bureau, Characteristics of New Single-Family Houses Completed, http://www.census.gov/construction/chars/completed.html.
} 
A fundamental finding from the research is that slab floors in central Florida's climate have low influence on space cooling based on experimental data. For most cooling periods, there was little to no significant energy difference, although there was evidence that the uncovered slab floor did exert some beneficial cooling influence during the spring period. There were no advantages of the exposed slab floor during the height of summer. On the contrary, on the very hottest days the carpeted floor showed reduced space cooling energy of $2 \%$.

During winter, the carpeted floor consistently showed lower space heating than the building with the exposed slab floor. During days with average temperatures colder than $55^{\circ} \mathrm{F}$, the carpeted building showed reductions in measured heating energy use of 3\% to $5 \%$ more than the uncarpeted building, even though its interior temperature remained approximately $0.5^{\circ} \mathrm{F}$ warmer than that of the uncarpeted building. This indicates that the savings estimate is likely conservative, which fits the expectation that slab heat transfer would be reduced by carpet and pad. Losses are greatest at the slab edge. No statistically significant differences were observed between the carpeted and uncarpeted buildings in terms of interior relative humidity or dew points during heating or cooling seasons.

An important caution when interpreting these data is that these results are highly sensitive to the geographic location where the data were taken and to the interior temperature conditions imposed in the experiments. However, it is important to note that the experimental results obtained contradicted commonly utilized simulation foundation model approximations used with Building Energy Optimization Software (running an EnergyPlus engine) or EnergyGauge USA software (running a DOE-2 engine). This questions underlying simplified foundation simulation models for slab floors, although better (and more complex) models exist - both for TRNSYS and EnergyPlus software. Better models need to be considered and implemented in light of empirical results. 


\section{Introduction}

Limited study of heat transfer to slab-on-grade foundations in cooling-dominated climates has been conducted during the last three decades of energy-efficiency research. Most experimental research has focused on the impact of slab-on-grade foundations and insulation schemes on heat losses in heating-dominated climates. There is a need to thoroughly evaluate slab floors because the floor area of slab-on-grade single-family homes is generally equal to wall area, window area, or attic area, all of which have been extensively evaluated for heat-transfer properties.

An early and very well done study by Bareither et al. (1948) at the University of Illinois compared the performance of seven types of slab floor insulation. Perhaps the most rigorous recent work was that of Adjali et al. (2000) at Cardiff School of Engineering in Wales, which compared numerical simulations to measured slab performance in detailed measurements. However, the deep-ground temperatures were quite cold in this British climate, and the work understandably focused only on heating losses from the slab.

Slab-on-grade construction is very popular in the cooling-dominated southern United States; $90 \%$ of Florida homes have slab floors as do a majority of homes in Texas and the Deep South. Moreover, data suggests that the fraction of U.S. homes built with slab floors has increased at the expense of basement- and crawlspace-type foundations. This is particularly true in the coolingdominated southern states where slab-on-grade construction accounts for $77 \%$ of new home floors according to 2014 U.S. Census data (Figure 1). ${ }^{2}$

\footnotetext{
${ }^{2}$ U.S. Census Bureau, Characteristics of New Single-Family Houses Completed, http://www.census.gov/construction/chars/completed.html.
} 


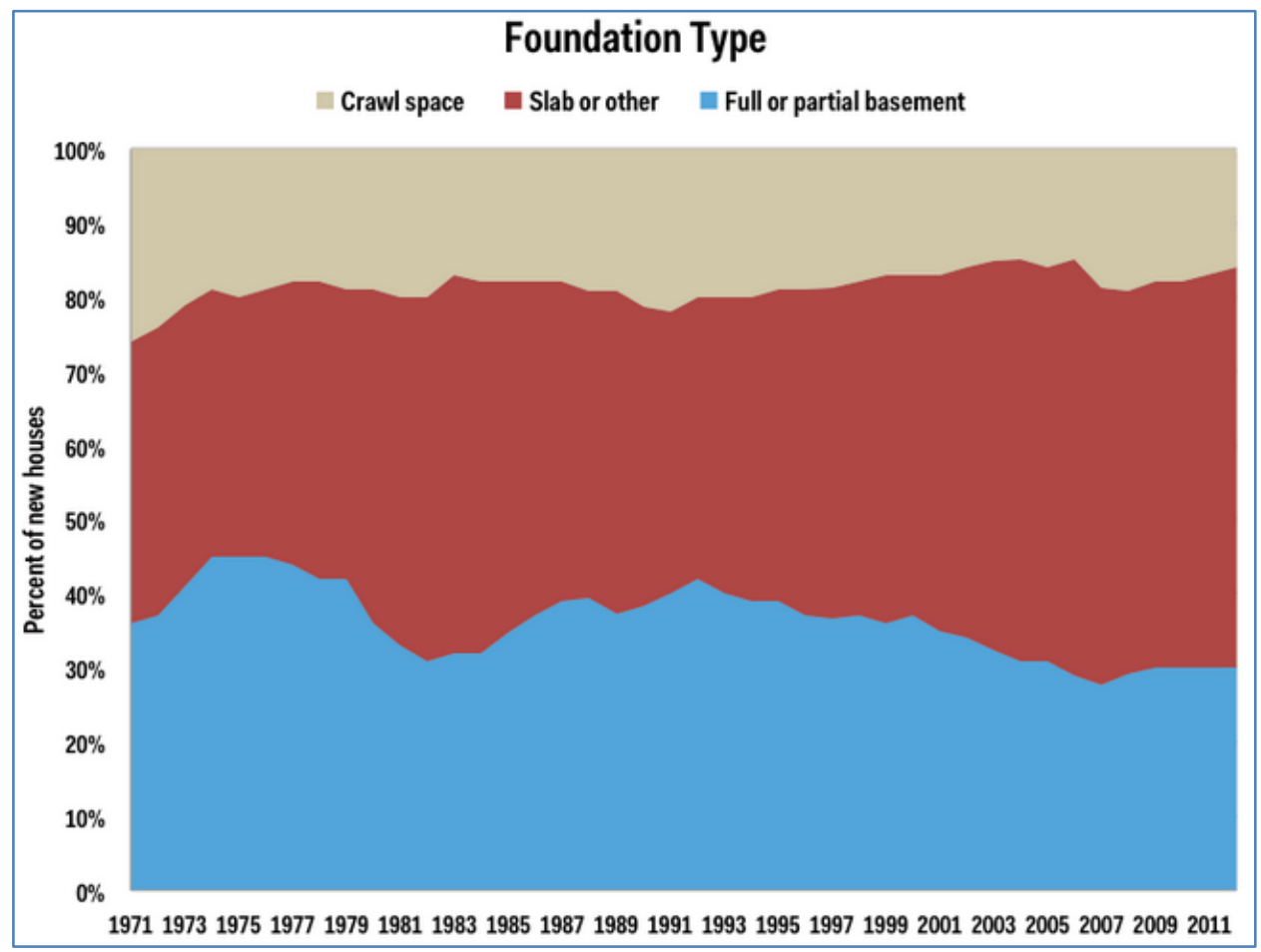

Figure 1. Percentage of new U.S. homes by foundation type. Image created from U.S. Department of Census data.

Because deep-ground temperature conditions are much warmer in cooling-dominated climates, a matter of some speculation has been how foundation heat transfer will influence cooling energy use. Empirical research is needed because building energy simulations such as DOE-2 and EnergyPlus often rely on simplified foundation models to evaluate these influences. For instance, simulations conducted for the project using EnergyPlus in Building Energy Optimization Software (BEopt) (using the Winkelmann approximations) loosely copying the test buildings generally indicate that a completely tiled slab-on-grade floor in the central Florida climate might be worth as much as a $4 \%$ to $7 \%$ reduction in space cooling. But how accurate are these approximations? Measured data are needed.

A widespread perception also exists that tile flooring, as opposed to carpet, provides a cooler home interior in warm climates. ${ }^{3}$ Indeed, historically tile flooring came into widespread use first in the warmer climate of ancient Greece and then spread to warmer regions in southern Italy, Spain, and Portugal. However, the impact of a tile floor on an occupant's comfort likely has more to do with conduction from bare feet into flooring rather than heating, ventilating, and airconditioning (HVAC) energy. ${ }^{4}$ Because tiles or concrete floors conduct heat well, skin will likely feel cooler on tile than on more insulating carpet. However, how carpet versus tile or concrete (terrazzo) influences the energy necessary to air condition the space is a very different question.

\footnotetext{
${ }^{3}$ Examples of the perceived cooling effects of tile: http://souds.com/cooling-effects-of-tile-flooring/, http://antranik.org/why-do-bare-feet-feel-much-colder-on-wood-and-tile-rather-than-on-carpet/ .

${ }^{4}$ Example of tile floor heat conduction: http://www.builddirect.com/blog/cool-flooring-in-the-summertime/.
} 


\section{Experiment Description}

The U.S. Department of Energy (DOE) Building America Partnership for Improved Residential Construction (BA-PIRC) team performed experiments over the course of 1 year from 2014 to 2015 in Cocoa, Florida, in the Florida Solar Energy Center's (FSEC) Flexible Residential Test Facility (FRTF). The experiments assessed the influence of slab-on-grade construction in a cooling-dominated climate for the first time. The FRTF consists of two 1,536- $\mathrm{ft}^{2}$ identical buildings that are extensively metered (Figure 2). The facility, which is conditioned year round, was completed in 2010 and has been used for a series of experiments. It is more thoroughly described in Vieira and Sherwin (2012).

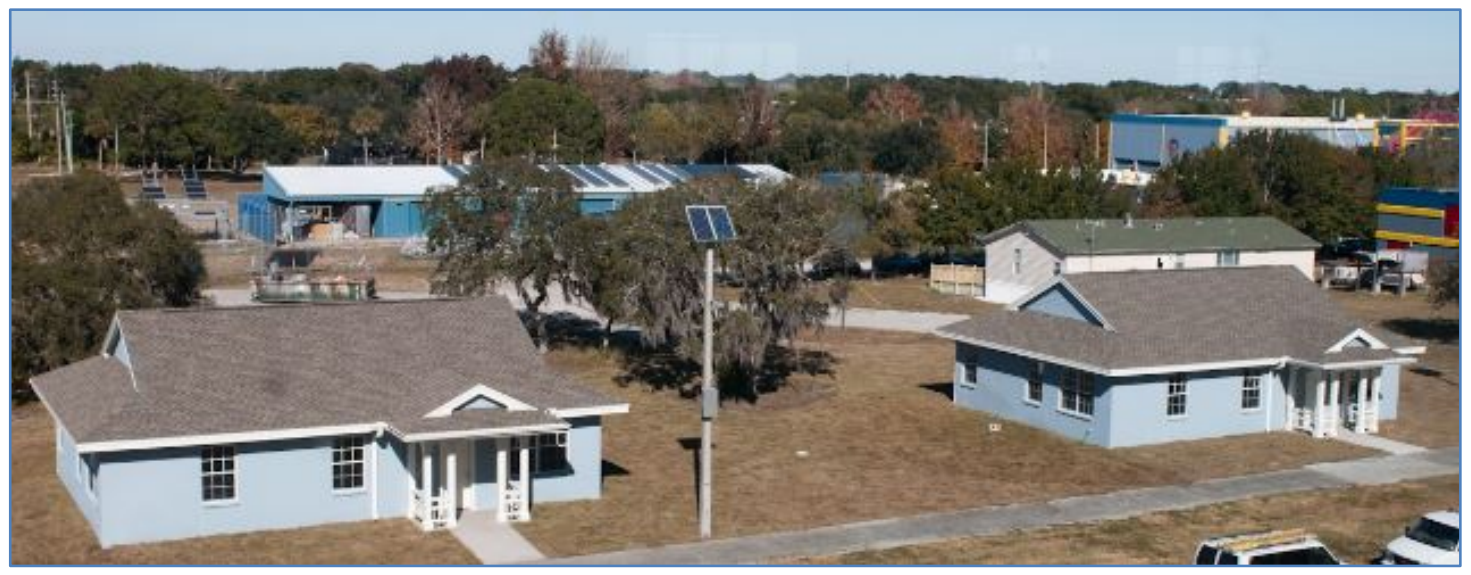

Figure 2. Side-by-side FRTF buildings at the FSEC Cocoa, Florida

Similar to many homes in the southern United States, each building has a standard 4-in. concrete monolithic slab as its floor, which was poured over sand fill at the time of construction. Not only were the experiments of 2014-2015 intended to examine how slab floors influence cooling, but also how the difference in a carpeted versus uncarpeted building might influence heating and cooling. The east test building had a standard $3 / 8$-in. rubber pad and $1 / 2$-in. synthetic carpet (which has compressed somewhat after installation) with a combined estimated R-value of approximately $2.4 \mathrm{hr}-\mathrm{ft}^{2}{ }^{\circ} \mathrm{F} / \mathrm{Btu} .{ }^{5}$ The west test building had the unmodified uncovered concrete slab floor.

In the research, FSEC evaluated the two side-by-side residential buildings, the east building with pad and carpet and the west building with a bare slab floor. The experimental apparatus used a Campbell Scientific CR7 measurement and control system with appropriate multiplexers and pulse count equipment to take the many measurements scanned every 10 seconds with 15 -minute averages stored (see Vieira and Sherwin [2012] for a more detailed explanation).

Each building was heated to $73^{\circ} \mathrm{F}$ for heating and cooled to $77^{\circ} \mathrm{F}$ using conventional identical thermostats in both building. To make the experiment representative of a conventional home, a conventional digital thermostat was used to control the heating and cooling system rather than other non-standard schemes. This resulted in a temperature that varied by up to $1^{\circ} \mathrm{F}$ from one

\footnotetext{
${ }^{5}$ Thermal resistance of floor coverings: http://www.carpetcushion.org/r-value.cfm.
} 
building to the next, but this was carefully adjusted in the pre-experimental phase to be as close as possible in the two buildings.

The heating set point may seem high, but is partially indicative of homeowners in Florida who are not well tolerant of cold interior temperatures, as well as the desire of the research team to create a little more heating season than what might otherwise exist during a central Florida winter. A grid of 164 temperature measurements were taken using copper-constantan (Type-T) thermocouples with a read resolution of $0.1^{\circ} \mathrm{F}$ and an uncertainty of $\pm 0.9^{\circ} \mathrm{F}$. Temperatures are taken on the slab surface as well as at depths of $1.0 \mathrm{ft}, 2.0 \mathrm{ft}, 5.0 \mathrm{ft}, 10.0 \mathrm{ft}$, and $20.0 \mathrm{ft}$. A schematic diagram of the measurement locations at the two FRTF buildings, both surface and descending down through the ground, is shown in Figure 3.

Some 164 type-T referenced and differentially measured thermocouples were recorded with a Campbell Scientific datalogger to define the slab and ground temperature domain of the two buildings in addition to air node temperatures, moisture, weather conditions, and heating and cooling system power. A summary of the measurements is shown in Table 1. The slab surface temperatures are as described; a type-T thermocouple cemented to the concrete floor. Points A1 through B6 were taken at 1.0-ft, 2.0-ft, 5.0-ft, 10.0-ft, and 20.0-ft depths. C1 - C6 measurements were taken at $1.0-\mathrm{ft}, 2.0-\mathrm{ft}, 5.0-\mathrm{ft}$, and $10.0-\mathrm{ft}$ depths while D1 -D6 measured temperatures at $1.0-\mathrm{ft}, 2.0-\mathrm{ft}$ and 5.0-ft. Point A2 was taken at the midpoint between the buildings, $32.5 \mathrm{ft}$ from the west and eastlabs. Point B3 was taken $2 \mathrm{ft}$ from the outside edge of the slab edge on the outside (Figure 3).

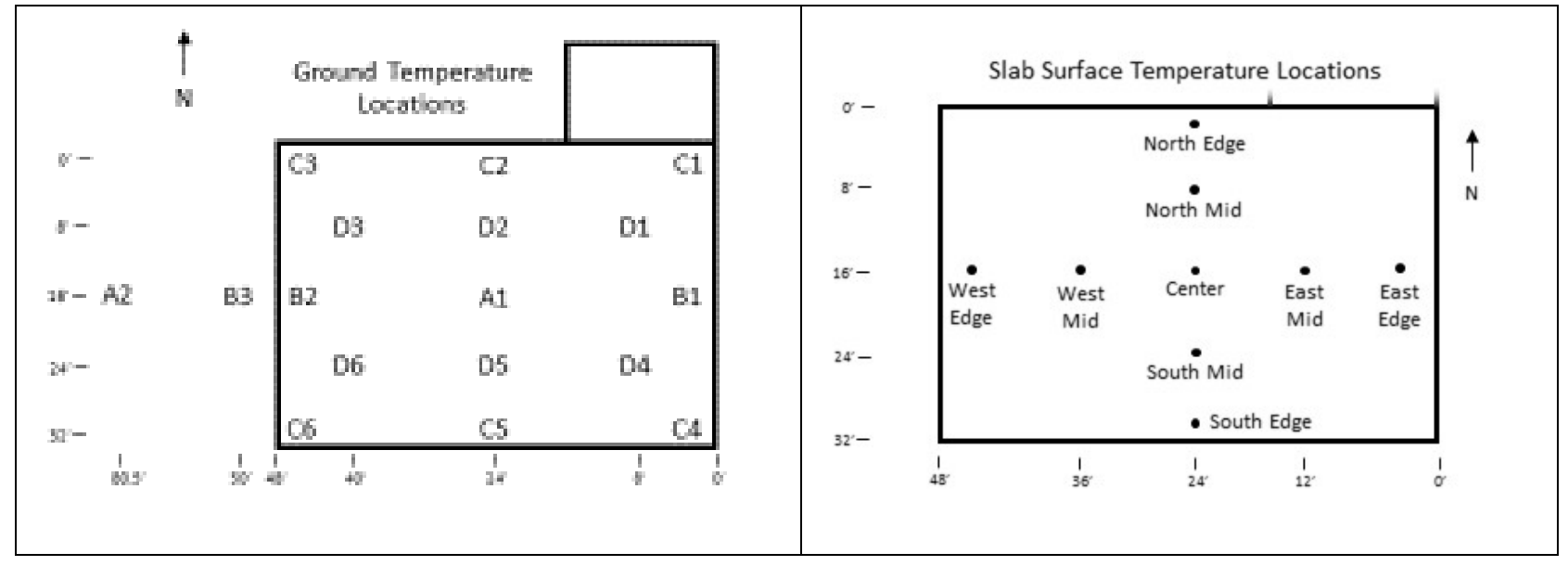

Figure 3. Schematic diagram of slab temperature measurement points at FRTF 
Table 1. Summary of Experimental Measurements

\begin{tabular}{|c|c|c|}
\hline Indoor Room Conditions & Type & Accuracy \\
\hline $\begin{array}{l}\text { Temp/Relative Humidity }(\mathrm{RH}) / \text { Dew } \\
\text { Point } \\
\text { Vaisala HMP50 Transmitters }\end{array}$ & Thin-film, dielectric capacitive & $0.5^{\circ} \mathrm{C} / 3 \% \mathrm{RH} / 0.8^{\circ} \mathrm{C}^{\circ}$ \\
\hline \multicolumn{3}{|l|}{ Slab and Ground Conditions } \\
\hline Temperature: copper-constantan & thermocouple & $0.5^{\circ} \mathrm{C}$ \\
\hline \multicolumn{3}{|l|}{ Energy Use } \\
\hline Air handler & pulse watt hr & $0.5 \%$ \\
\hline Condenser & pulse watt hr & $0.5 \%$ \\
\hline Weather & Type & Stated Accuracy \\
\hline Outdoor temperature/RH & & \\
\hline $\begin{array}{l}\text { Vaisala HMP50 Transmitters } \\
\text { Redundant measurement: Type-T } \\
\text { thermocouple in vented gill plate }\end{array}$ & Thin-film, dielectric capacitive & $0.5^{\circ} \mathrm{C} / 3 \% \mathrm{RH}$ \\
\hline
\end{tabular}

Surface heat flux measurements were not taken. Although surface heat flux measurements would have been desirable, they are expensive (nearly $\$ 400$ per measurement point), putting this out of reach for the project when initially constructed and instrumented. Instead thermal characterization depended on a network of surface and depth temperature measurements along with building interior temperatures as well as calibrated power measurements of the system heating and cooling energy in both buildings. To help with this limitation the team estimated "surrogate fluxes" by subtracting the interior measured air temperature from the various slab surface temperature measurement points. This then provides insight relative to heat flow direction and magnitude.

Ultimately the team decided that measured changes to heating and cooling energy were the most important influences to be examined in the project. ${ }^{6}$

Cooling is provided by a 3 -ton seasonal energy efficiency ratio (SEER) 13 air conditioner (not a heat pump). The buildings are heated by a $10-\mathrm{kW}$ electric resistance heating coil within the air handling unit. The envelope for each is meant to represent older building stock in Florida with R19 ceiling, uninsulated concrete block walls, and single-pane glass windows with blinds. The homes have imposed internal heat gains as well as moisture release to mimic standard conditions in occupied Florida single-family homes. The internal heat gains and schedule with which they are imposed are given in the instrumentation plan for the facility by Vieira and Sherwin (2012).

\footnotetext{
${ }^{6}$ In the future, researchers would like to install up to three heat flux transducers in each building (near a surface temperature measurement point) and collect associated data to compare existing temperature data to heat flux measurements.
} 


\section{Experimental Results}

To evaluate the impact of slab foundation heat transfer on heating and cooling energy ground thermal behavior, soil thermal properties, and slab thermal performance were experimentally determined under floating conditions and under heating, heavy cooling, and light cooling. Surrogate heat fluxes were calculated from the data.

\subsection{Measured Ground Thermal Behavior}

Temperatures were measured east of the two test buildings in an open area (location A2 in Figure 3 ) at varying depths from the surface to 20 -ft below the ground surface. This point is midway between the two buildings and is $32.5 \mathrm{ft}$ away from either structure. The ground surface around the FRTF buildings is conventional relative to a suburban environment with short grass and standard sandy soils as encountered in central Florida. Figure 4 presents the average temperature profiles over an entire year and compares this with the ambient air temperature recorded at the site weather station.

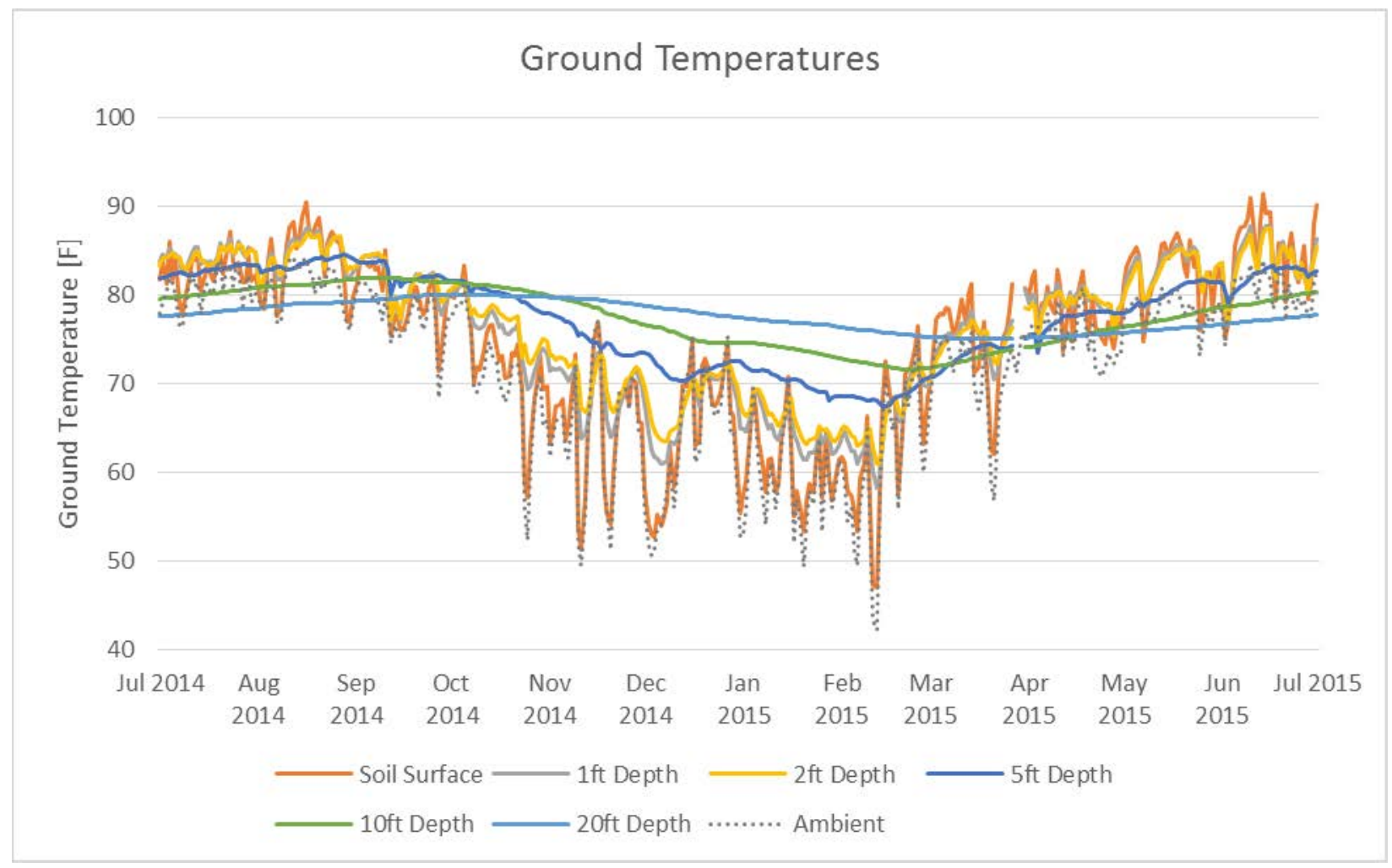

Figure 4. Measured daily average temperatures: July 9, 2014, to July 9, 2015, at varying depths versus ambient air temperature

Point A2 is $32.5 \mathrm{ft}$ from the west and east walls of the two test buildings, respectively. The temperature at the soil surface is actually a measurement of the grassy surface. The thermocouple is protected by a surrounding hollow concrete block to avoid damage from lawn equipment. That measurement and the 1-ft depth shows pronounced impact from heating of the soil surface in summer compared with the shielded ambient air temperature. The soil surface temperature 
closely tracks the ambient air temperature in winter when there is less solar radiation. The temperatures of the ground at $10-\mathrm{ft}$ and $20-\mathrm{ft}$ depths change slowly and increasingly out of phase with the temperature of the layers and air above. The monthly averages are shown in Table 2 below.

Table 2. Monthly Undisturbed Ground Temperature at FRTF: July 1, 2014, to July 1, 2015

\begin{tabular}{lrcccccr}
\hline Date & Soil/AirSurface & $\begin{array}{c}\text { 1-ft } \\
\text { Depth }\end{array}$ & $\begin{array}{c}\text { 2-ft } \\
\text { Depth }\end{array}$ & $\begin{array}{c}\text { 5-ft } \\
\text { Depth }\end{array}$ & $\begin{array}{c}\text { 10-ft } \\
\text { Depth }\end{array}$ & $\begin{array}{c}\text { 20-ft } \\
\text { Depth }\end{array}$ & Ambient \\
\hline Jul 2014 & 82.08 & 83.95 & 83.92 & 82.57 & 79.81 & 77.77 & 80.00 \\
\hline Aug 2014 & 84.15 & 84.76 & 84.60 & 83.38 & 81.01 & 78.77 & 81.32 \\
\hline Sep 2014 & 81.00 & 82.53 & 82.77 & 83.07 & 81.80 & 79.49 & 78.75 \\
\hline Oct 2014 & 75.89 & 78.33 & 79.15 & 80.98 & 81.17 & 79.98 & 73.98 \\
\hline Nov 2014 & 64.96 & 69.92 & 71.54 & 76.43 & 79.26 & 79.61 & 63.48 \\
\hline Dec 2014 & 64.40 & 67.18 & 68.20 & 71.91 & 75.97 & 78.48 & 63.66 \\
\hline Jan 2015 & 62.26 & 66.30 & 67.47 & 71.22 & 74.27 & 77.18 & 60.59 \\
\hline Feb 2015 & 60.47 & 63.61 & 64.61 & 68.39 & 72.50 & 76.13 & 58.61 \\
\hline Mar 2015 & 73.44 & 73.64 & 73.54 & 72.15 & 72.40 & 75.20 & 69.96 \\
\hline Apr 2015 & 78.88 & 79.08 & 78.71 & 76.44 & 74.78 & 75.31 & 75.46 \\
\hline May 2015 & 81.34 & 81.97 & 81.73 & 79.32 & 76.86 & 75.97 & 77.11 \\
\hline Jun 2015 & 83.74 & 83.75 & 83.56 & 81.84 & 78.94 & 76.94 & 79.70 \\
\hline Annual Average & $\mathbf{7 4 . 4 5}$ & $\mathbf{7 6 . 3 2}$ & $\mathbf{7 6 . 7 2}$ & $\mathbf{7 7 . 3 8}$ & $\mathbf{7 7 . 4 6}$ & $\mathbf{7 7 . 6 0}$ & $\mathbf{7 1 . 8 5}$ \\
\hline
\end{tabular}

The annual averages show that soil surface temperatures are considerably higher than the ambient air temperature (a known fact from previous investigations: e.g., Mount and Paetzold 2002) and that this has implications for the thermal environment moving down through the ground. The average ambient air temperature over the period was $71.9^{\circ} \mathrm{F}$, but the surface temperature as exposed to solar insolation was $74.5^{\circ} \mathrm{F}$. The more stable and smoothly varying temperature at a $20-\mathrm{ft}$ depth was $77.6^{\circ} \mathrm{F}$. The maximum surface temperature $\left(84.8^{\circ} \mathrm{F}\right)$ comes in September, the minimum $\left(63.6^{\circ} \mathrm{F}\right)$ comes in February. At a $20-\mathrm{ft}$ depth, the amplitude is much lower and 1 month out of phase with the surface behavior: the maximum $\left(80.0^{\circ} \mathrm{F}\right)$ comes in October and the minimum $\left(75.2^{\circ} \mathrm{F}\right)$ is seen in March. When evaluated over a daily interval, the lowest ambient temperature occurs on Day 52 or February $21\left(42.2^{\circ} \mathrm{F}\right)$, but the lowest surface temperature is recorded on Day 46 or February $15\left(60.9^{\circ} \mathrm{F}\right)$ after a period of low solar irradiance. The lowest temperature at a 20 -ft depth $\left(75.1^{\circ} \mathrm{F}\right)$ is seen on Day 85 (March 26).

\subsection{Measured and Estimated Soil Thermal Properties}

Over the course of the project, we obtained a sample of the below-grade soils from the test site and evaluated the soil by weight and volume. The soil sample reveals many fines with some loam and silt, and low plasticity. Evaluation under the Unified Soil Classification System (USCS) would likely be designated as SW-SM: sand with diversified particle size and sand with silt (Evett and Liu 2007). The team found that the soil sample density was $1,325.5 \mathrm{~kg} / \mathrm{m}^{3}$. The team evaluated several sub-samples of the soil sample collected, and through laboratory drying established that the in situ soil moisture content was $4.3 \%$ to $4.6 \%$. 
These data were used to estimate the soil thermal diffusivity according to the harmonic analysis procedure recommended by Kusuda and Achenbach (1965). Details from the estimating procedure are provided in Appendix A.

By substituting measured data in Tables 1 and 2 into the last two equations in Appendix A, the diffusivities calculated by amplitudes $(\mathrm{B})$ and phase angles $(\mathrm{P})$ are approximated with different depth differences shown in Table 3.

Table 3. Estimated Soil Thermal Diffusivity Using the First Order Harmonic Approach

\begin{tabular}{cccccccc}
\hline & \multicolumn{3}{c}{$\Delta \mathbf{x}(\mathbf{f t})$} & \multicolumn{3}{c}{ Average } \\
\cline { 2 - 8 } & 0.901575 & 1 & 3 & 5 & 10 & $\mathrm{ft}^{2} / \mathrm{h}$ & $\mathrm{m}^{2} / \mathrm{s}$ \\
a_B $^{\text {a_P }}$ & 0.012978 & 0.061681 & 0.027740 & 0.034065 & 0.082530 & 0.043800 & $1.13 \mathrm{E}-06$ \\
\hline
\end{tabular}

Thus, soil diffusivity is estimated at approximately $1.03 \mathrm{ft}^{2} / \mathrm{d}$ for the soils under the FRTF buildings. This would represent very wet sandy soils given the classification of Kusuda and Harrington (1982) and the upper end of measured diffusivities described by Kusuda and Achenbach (1965). Given that the soil density was measured at $1,325.5 \mathrm{~kg} / \mathrm{m}^{3}$ and specific heat is assumed to be $1,000 \mathrm{~J} / \mathrm{kg}^{\circ} \mathrm{C}$ with some level of wetness, the soil conductivity may be estimated at $1.49 \mathrm{~W} / \mathrm{m}^{\circ} \mathrm{K}\left(0.86 \mathrm{Btu} / \mathrm{hr}-\mathrm{ft}-{ }^{\circ} \mathrm{F}\right)$, which is similar to the mid-range for moist sandy soils. $^{7}$

\subsection{Floor Slab Thermal Performance}

Similar to the undisturbed ground temperature at location A2, we also examined the various center-of-building slab temperatures, both surface and at depth, located at A1 in Figure 3. Examples for the center slab temperature profiles in Figure 5 and Figure 6 show strong thermal heat flow from the interior building to the ground from the uncooled spring period, which is quite apparent to a depth of $5 \mathrm{ft}$. The widely varying shallow temperatures shown between October 31, 2014, and April 2015 come during Florida's "heating season" when the cooling system is not available and the temperature inside the building is allowed to float upward above $73^{\circ} \mathrm{F}$, but not below. However, this period of time with higher floating interior temperatures creates prominent heat flows evident down through the slab and into the ground layers as shown by the data.

During this time, the building is floating above the heating set point, a circumstance that is common in Florida homes during the winter months when space conditioning is quite low except for infrequent cold snaps. In particular, the data show that the uncovered slab floor in the west building is creating surface temperatures approximately $1^{\circ} \mathrm{F}$ lower than shown for the east carpeted building. This can be clearly seen in the deeper soil levels all the way down to $5 \mathrm{ft}$ below the surface, which are approximately $1^{\circ} \mathrm{F}$ warmer in the uncovered floor.

Table 4 and Table 5 list the numerical data for the slab and ground temperatures under the center slab location in the two buildings over the entire year, when summarized monthly. Figure 5 and

\footnotetext{
${ }^{7}$ Thermal conductivity of materials and gases: http://www.engineeringtoolbox.com/thermal-conductivityd $429 . \mathrm{html}$
} 
Figure 6 show the same data when evaluated daily over the entire year and graphed for the east and west buildings.

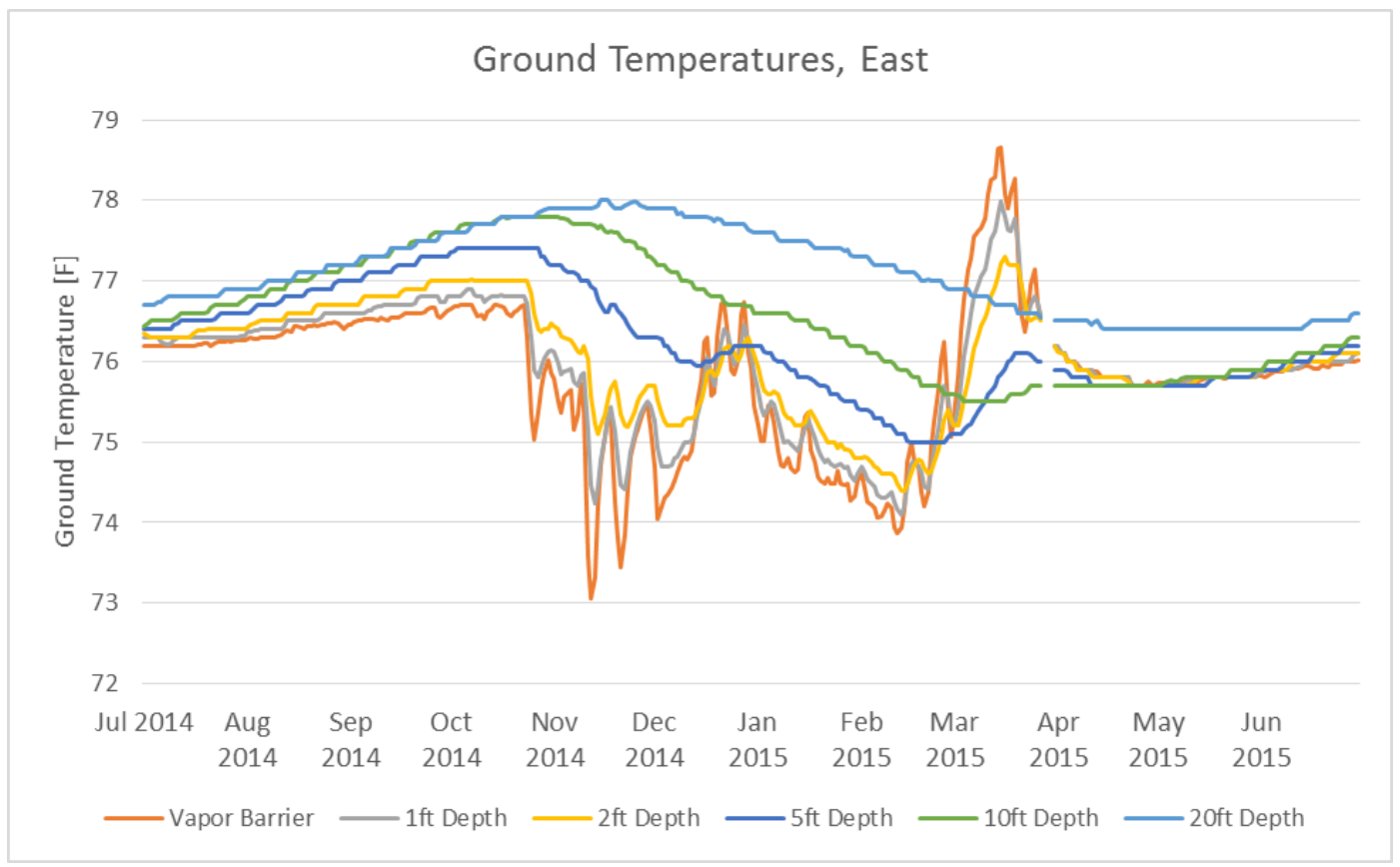

Figure 5. Center slab daily temperature profiles for July 9, 2014, to July 9, 2015, for the carpeted east building

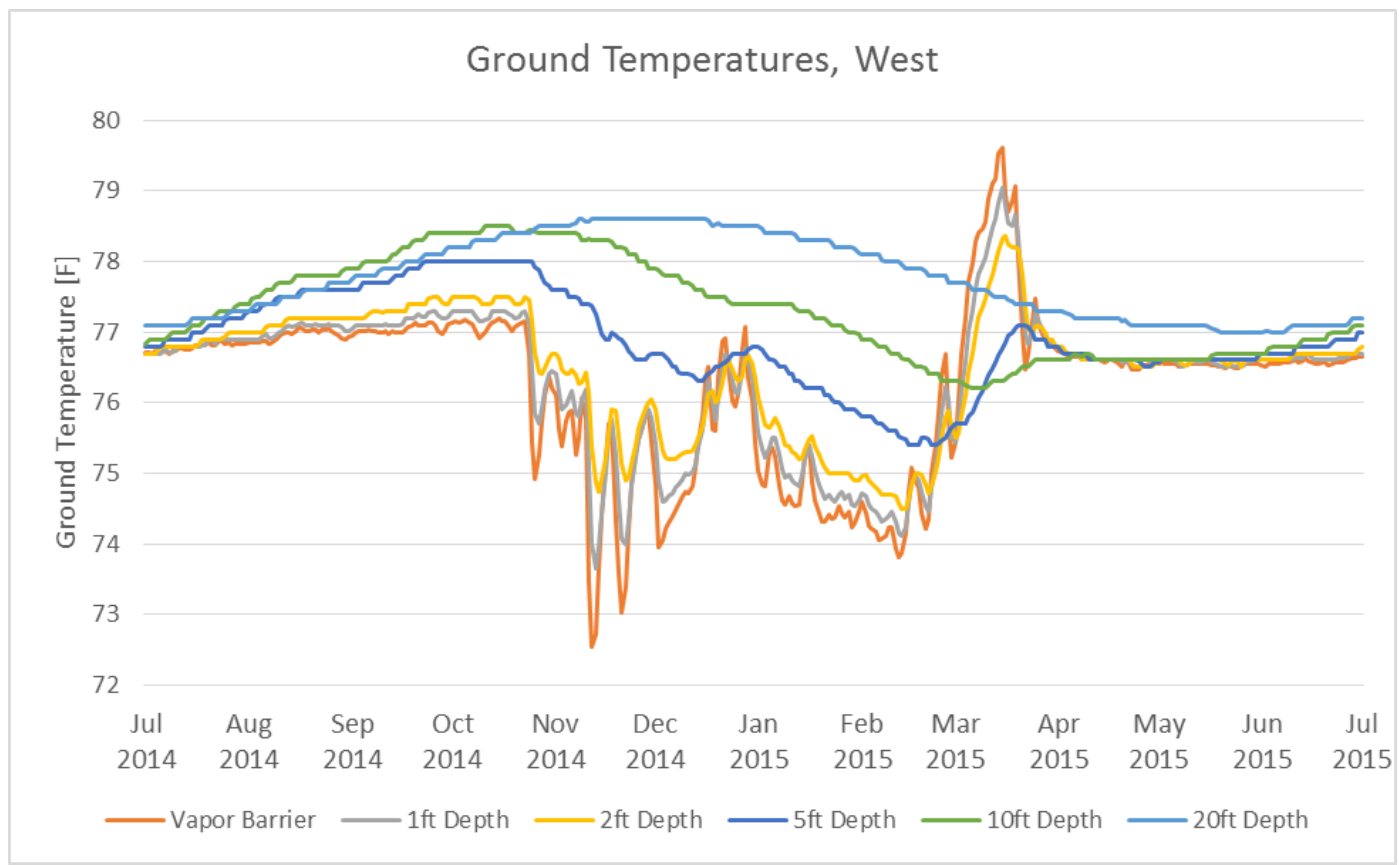

Figure 6. Center slab daily temperature profiles for July 9, 2014, to July 9, 2015, for the concretefloored west building 
Table 4. Monthly Ground Temperature Under the Carpeted East Building at FRTF Experiment: July 1, 2014, to June 30, 2015

\begin{tabular}{lrrrrrrr}
\hline Date & $\begin{array}{c}\text { Vapor } \\
\text { Barrier }\end{array}$ & $\begin{array}{c}\text { 1-ft } \\
\text { Depth }\end{array}$ & $\begin{array}{c}\text { 2-ft } \\
\text { Depth }\end{array}$ & $\begin{array}{c}\text { 5-ft } \\
\text { Depth }\end{array}$ & $\begin{array}{c}\text { 10-ft } \\
\text { Depth }\end{array}$ & $\begin{array}{c}\text { 20-ft } \\
\text { Depth }\end{array}$ & Ambient \\
\hline Jul 2014 & 76.25 & 76.31 & 76.36 & 76.44 & 76.52 & 76.76 & 80.00 \\
\hline Aug 2014 & 76.33 & 76.41 & 76.51 & 76.73 & 76.87 & 76.98 & 81.32 \\
\hline Sep 2014 & 76.52 & 76.66 & 76.78 & 77.08 & 77.29 & 77.31 & 78.75 \\
\hline Oct 2014 & 76.64 & 76.80 & 77.00 & 77.37 & 77.69 & 77.67 & 73.98 \\
\hline Nov 2014 & 75.02 & 75.51 & 76.02 & 77.01 & 77.71 & 77.90 & 63.48 \\
\hline Dec 2014 & 75.20 & 75.30 & 75.53 & 76.14 & 77.09 & 77.85 & 63.66 \\
\hline Jan 2015 & 75.19 & 75.38 & 75.57 & 75.97 & 76.56 & 77.54 & 60.59 \\
\hline Feb 2015 & 74.35 & 74.50 & 74.71 & 75.27 & 76.05 & 77.22 & 58.61 \\
\hline Mar 2015 & 76.89 & 76.49 & 76.11 & 75.47 & 75.57 & 76.81 & 69.96 \\
\hline Apr 2015 & 76.04 & 76.02 & 75.98 & 75.80 & 75.70 & 76.48 & 75.46 \\
\hline May 2015 & 75.75 & 75.74 & 75.74 & 75.72 & 75.76 & 76.40 & 77.11 \\
\hline Jun 2015 & 75.88 & 75.91 & 75.92 & 75.95 & 76.02 & 76.43 & 79.70 \\
\hline Annual Average & $\mathbf{7 5 . 8 4}$ & $\mathbf{7 5 . 9 2}$ & $\mathbf{7 6 . 0 2}$ & $\mathbf{7 6 . 2 5}$ & $\mathbf{7 6 . 5 7}$ & $\mathbf{7 7 . 1 1}$ & $\mathbf{7 1 . 8 9}$ \\
\hline
\end{tabular}

Table 5. Monthly Ground Temperature Under the Uncarpeted West Building at FRTF Experiment: July 1, 2014, to June 30, 2015

\begin{tabular}{lrrrrrrr}
\hline Date & $\begin{array}{c}\text { Vapor } \\
\text { Barrier }\end{array}$ & $\begin{array}{c}\text { 1-ft } \\
\text { Depth }\end{array}$ & $\begin{array}{c}\text { 2-ft } \\
\text { Depth }\end{array}$ & $\begin{array}{c}\text { 5-ft } \\
\text { Depth }\end{array}$ & $\begin{array}{c}\text { 10-ft } \\
\text { Depth }\end{array}$ & $\begin{array}{c}\text { 20-ft } \\
\text { Depth }\end{array}$ & Ambient \\
\hline Jul 2014 & 76.77 & 76.77 & 76.79 & 76.87 & 76.97 & 77.13 & 80.00 \\
\hline Aug 2014 & 76.92 & 76.99 & 77.09 & 77.4 & 77.59 & 77.42 & 81.32 \\
\hline Sep 2014 & 77.01 & 77.12 & 77.27 & 77.72 & 78.01 & 77.84 & 78.75 \\
\hline Oct 2014 & 77.10 & 77.26 & 77.46 & 78.00 & 78.43 & 78.26 & 73.98 \\
\hline Nov 2014 & 75.06 & 75.54 & 76.09 & 77.41 & 78.34 & 78.54 & 63.48 \\
\hline Dec 2014 & 75.27 & 75.40 & 75.65 & 76.53 & 77.75 & 78.58 & 63.66 \\
\hline Jan 2015 & 75.14 & 75.40 & 75.70 & 76.47 & 77.34 & 78.39 & 60.59 \\
\hline Feb 2015 & 74.34 & 74.55 & 74.83 & 75.69 & 76.80 & 78.05 & 58.61 \\
\hline Mar 2015 & 77.41 & 77.11 & 76.81 & 76.19 & 76.32 & 77.60 & 69.96 \\
\hline Apr 2015 & 76.73 & 76.74 & 76.74 & 76.71 & 76.61 & 77.24 & 75.46 \\
\hline May 2015 & 76.53 & 76.55 & 76.56 & 76.58 & 76.62 & 77.08 & 77.11 \\
\hline Jun 2015 & 76.55 & 76.59 & 76.64 & 76.72 & 76.81 & 77.04 & 79.70 \\
\hline Annual Average & $\mathbf{7 6 . 2 4}$ & $\mathbf{7 6 . 3 4}$ & $\mathbf{7 6 . 4 7}$ & $\mathbf{7 6 . 8 6}$ & $\mathbf{7 7 . 3 0}$ & $\mathbf{7 7 . 7 6}$ & $\mathbf{7 1 . 8 9}$ \\
\hline
\end{tabular}




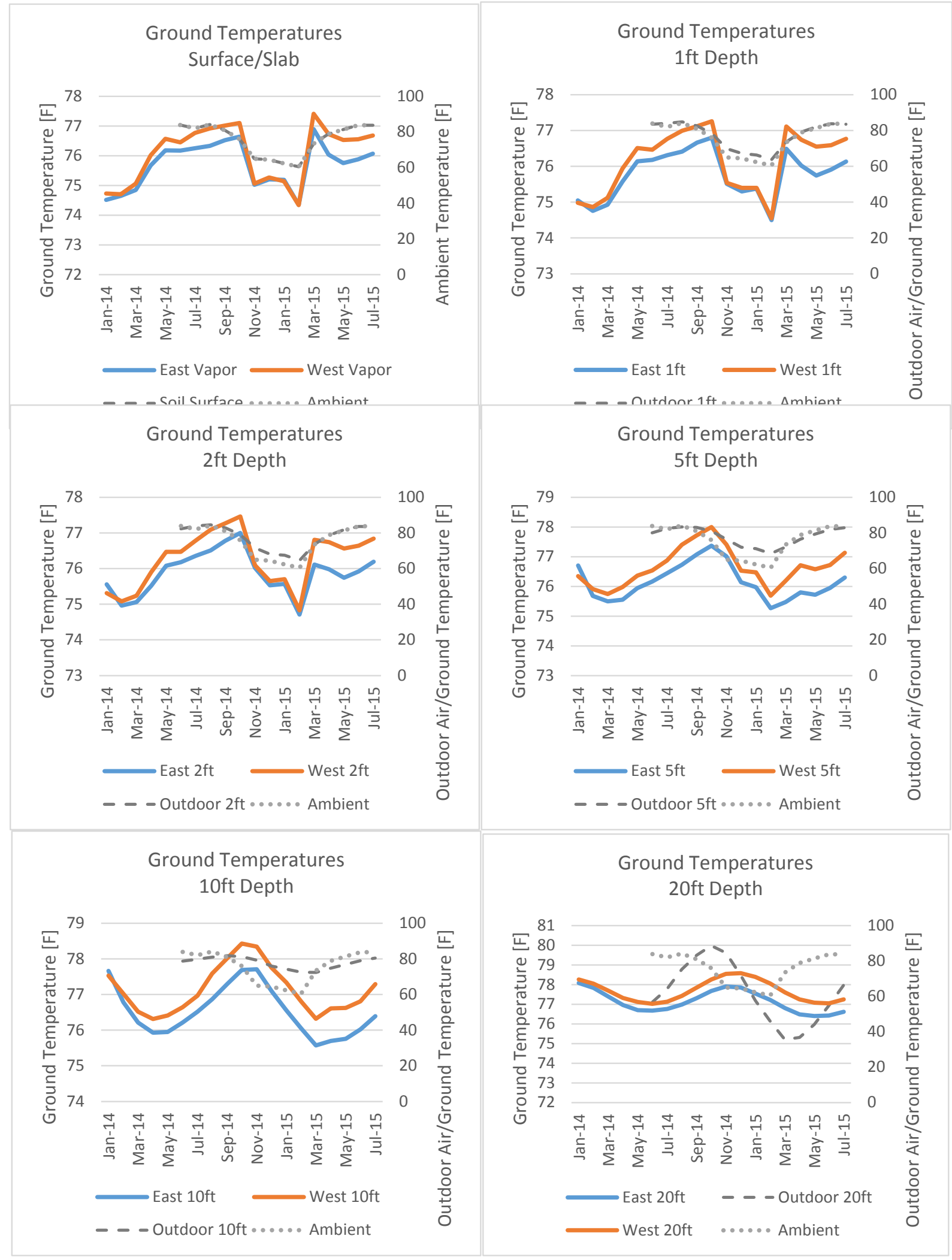

Figure 7. Comparison between the carpeted east building and uncarpeted west building 
Given the numerical data and numerous measurement locations (153 ground and sub-slab and slab surface temperatures), to understand the relevant thermal phenomenon we computed thermal contour plots (shown later as Figure 19, Figure 23, Figure 24, and Figure 25) for each period of analysis evaluated. We examined three periods for analysis: (1) where the space-conditioning system was in heating mode, (2) during floating periods in the spring of 2015, and (3) during two periods of cooling: moderate cooling defined as days with an average dew point temperature of $70^{\circ} \mathrm{F}$, and in heavy cooling days defined as those above $70^{\circ} \mathrm{F}$. These slab data are presented within each of the relevant sections below as a series of contour plots as well as tabulated temperatures in the summary where the heating and cooling energy data is reported.

\subsection{Estimated Surrogate Heat Fluxes}

To address the lack of physical measurement of heat fluxes, we estimated "surrogate heat fluxes" from the available temperature data. These were estimated by subtracting the measured slab surface temperature from the measured interior air temperature. These have the units $\Delta \mathrm{T}\left({ }^{\circ} \mathrm{F}\right)$ and, while not true heat fluxes, give an indication of heat flow direction and order of magnitude. ${ }^{8}$ The measured values on the east carpeted section reflect the measured temperature under the carpet and pad and have been divided by the R-value of that assembly $\left(2.4 \mathrm{hr}-\mathrm{ft}^{2}-{ }^{\circ} \mathrm{F} / \mathrm{Btu}\right)$ to yield a comparative value to that shown for the west side, which is exposed to the interior air. The two-letter codes used in the graphs below are "ne" for North Edge, "nm" for North Mid, and so on as shown in Figure 8.

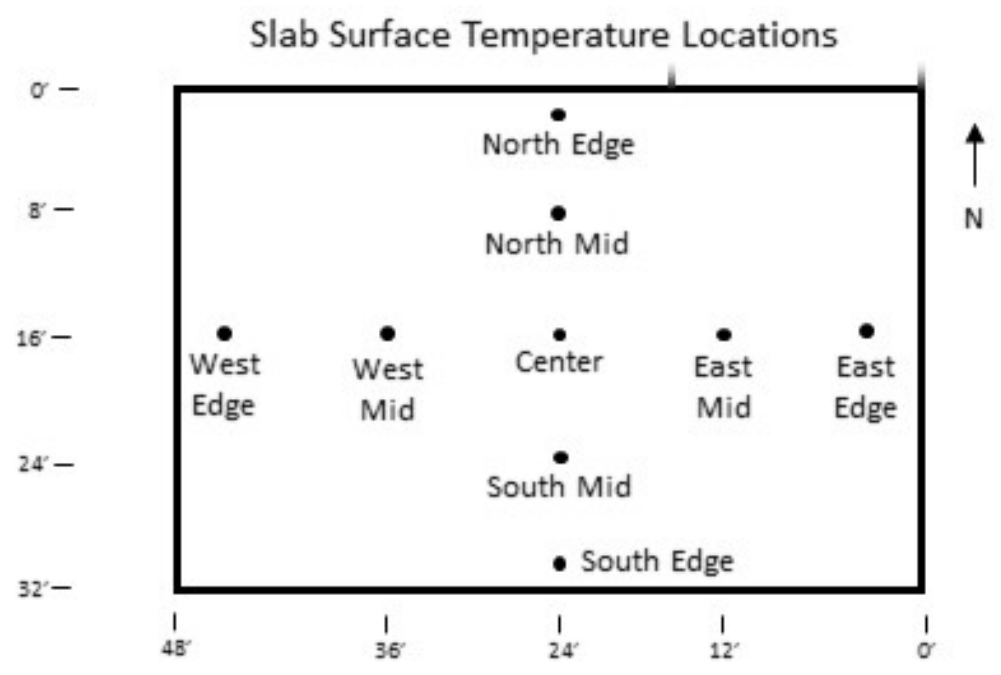

Figure 8. Slab surface temperature locations

The hourly plots of the surrogate heat fluxes are reproduced below both for the carpeted east building and the uncarpeted west building with the exposed slab. Positive numbers indicated heat gain to the space; negative values indicate heat losses from the slab. Note some missing data for January for the north slab edge data.

\footnotetext{
${ }^{8}$ As an approximation, it can be considered that the horizontal heat transfer conductances from the 2009 ASHRAE Handbook of Fundamentals (Table 1, p. 26.2) are 1.63 Btu/ $/ \mathrm{ft}^{2}-^{\circ} \mathrm{F}$ for heat transfer upward and 1.08 for heat transfer downward.
} 


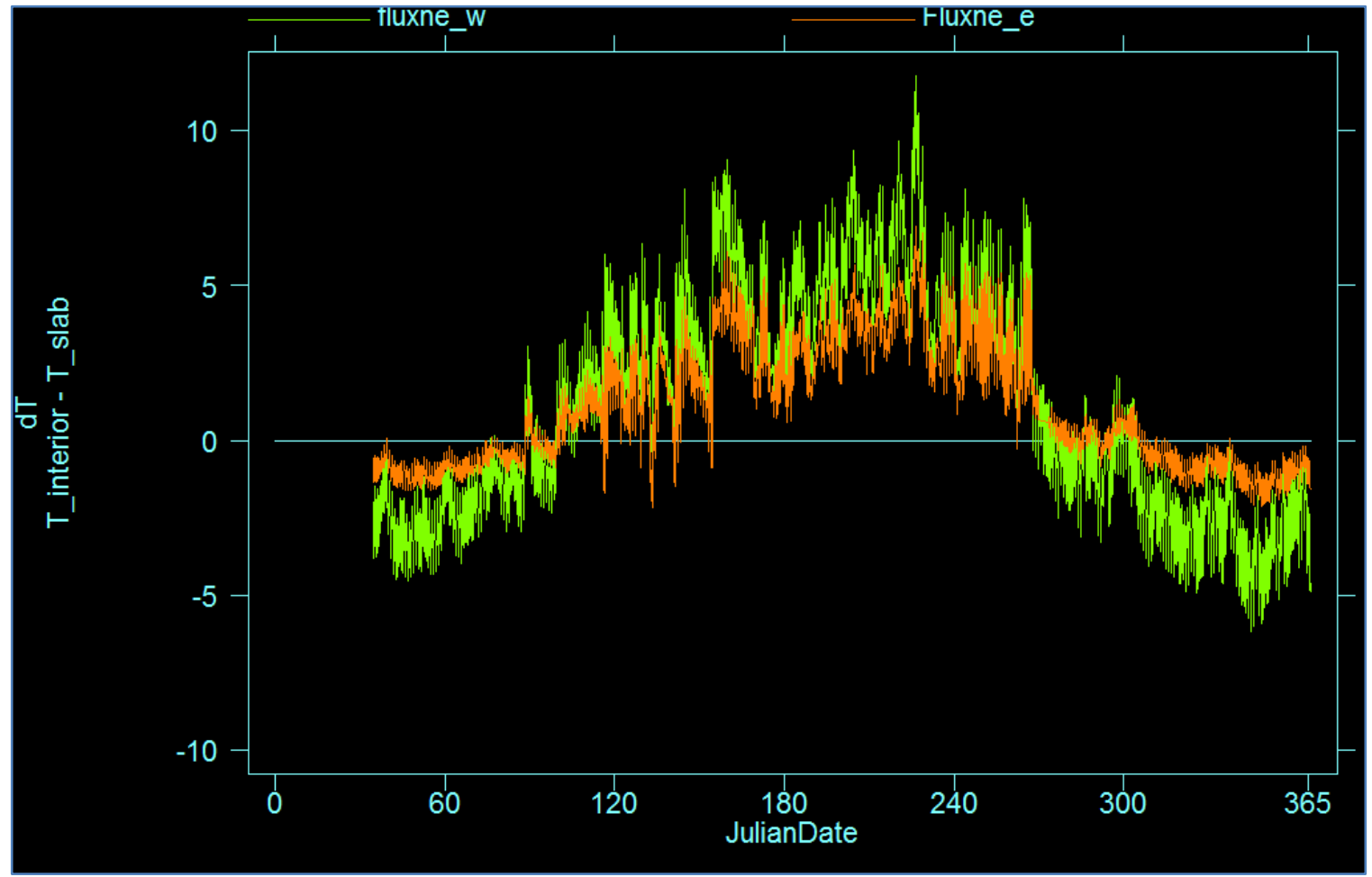

Figure 9. North edge surrogate heat fluxes $(\Delta T)$ : Green (west exposed), brown (east carpeted)

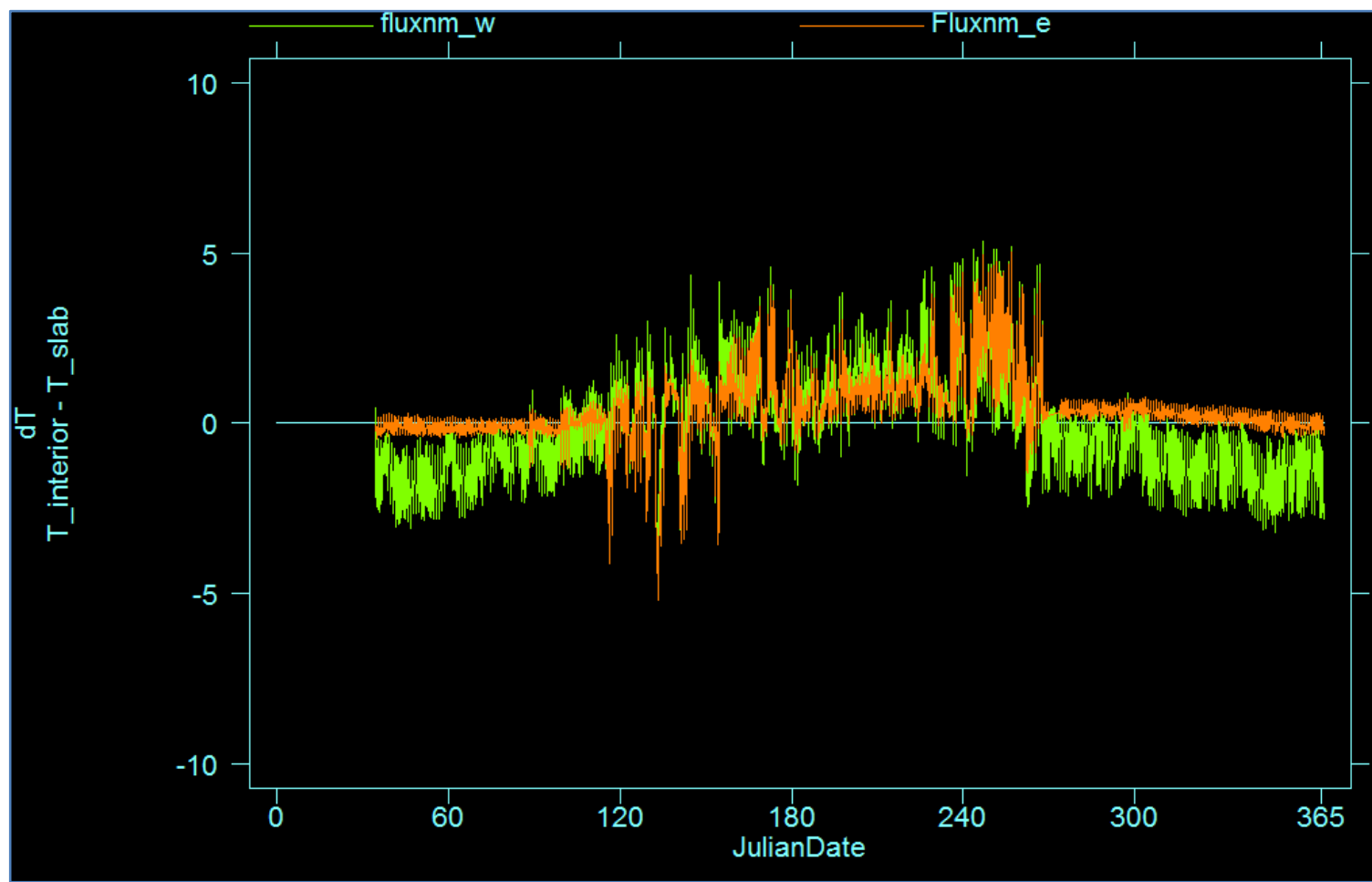

Figure 10. North midpoint surrogate fluxes $(\Delta T)$ : Green (west exposed), brown (east carpeted) 


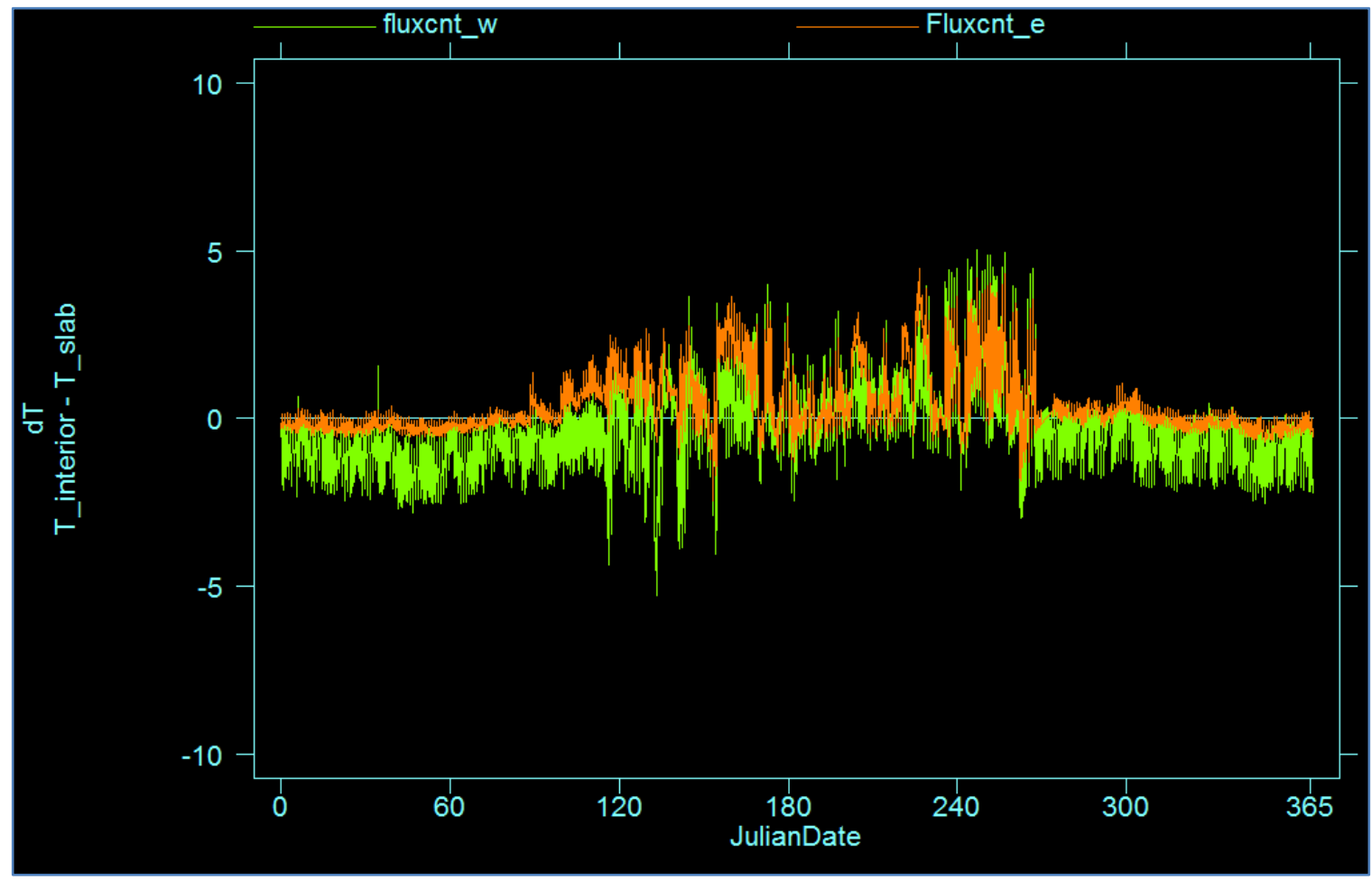

Figure 11. Slab floor center surrogate fluxes $(\Delta T)$ : Green (west exposed), brown (east carpeted)

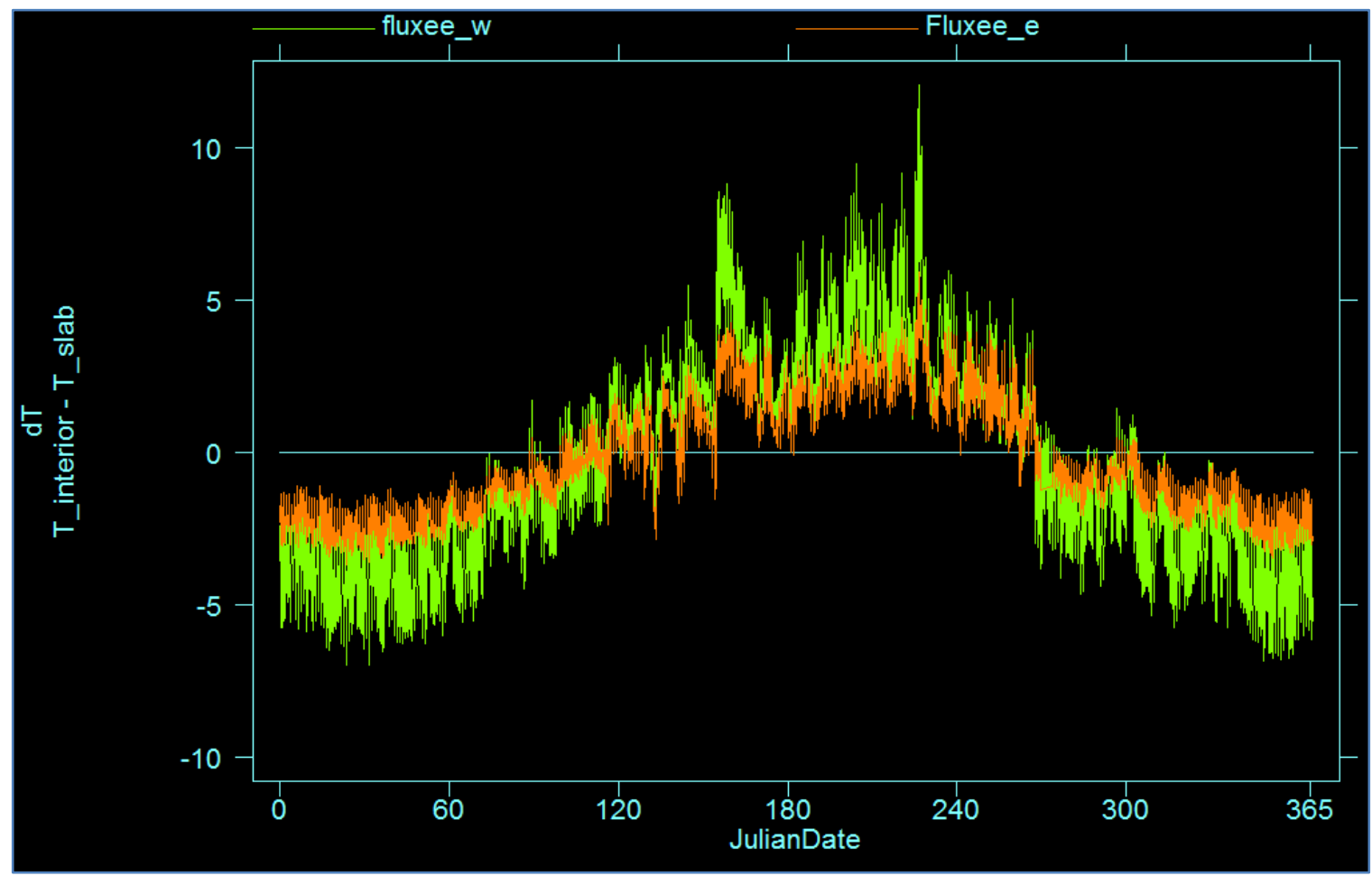

Figure 12. East edge surrogate fluxes $(\Delta T)$ : Green (west exposed), brown (east carpeted) 


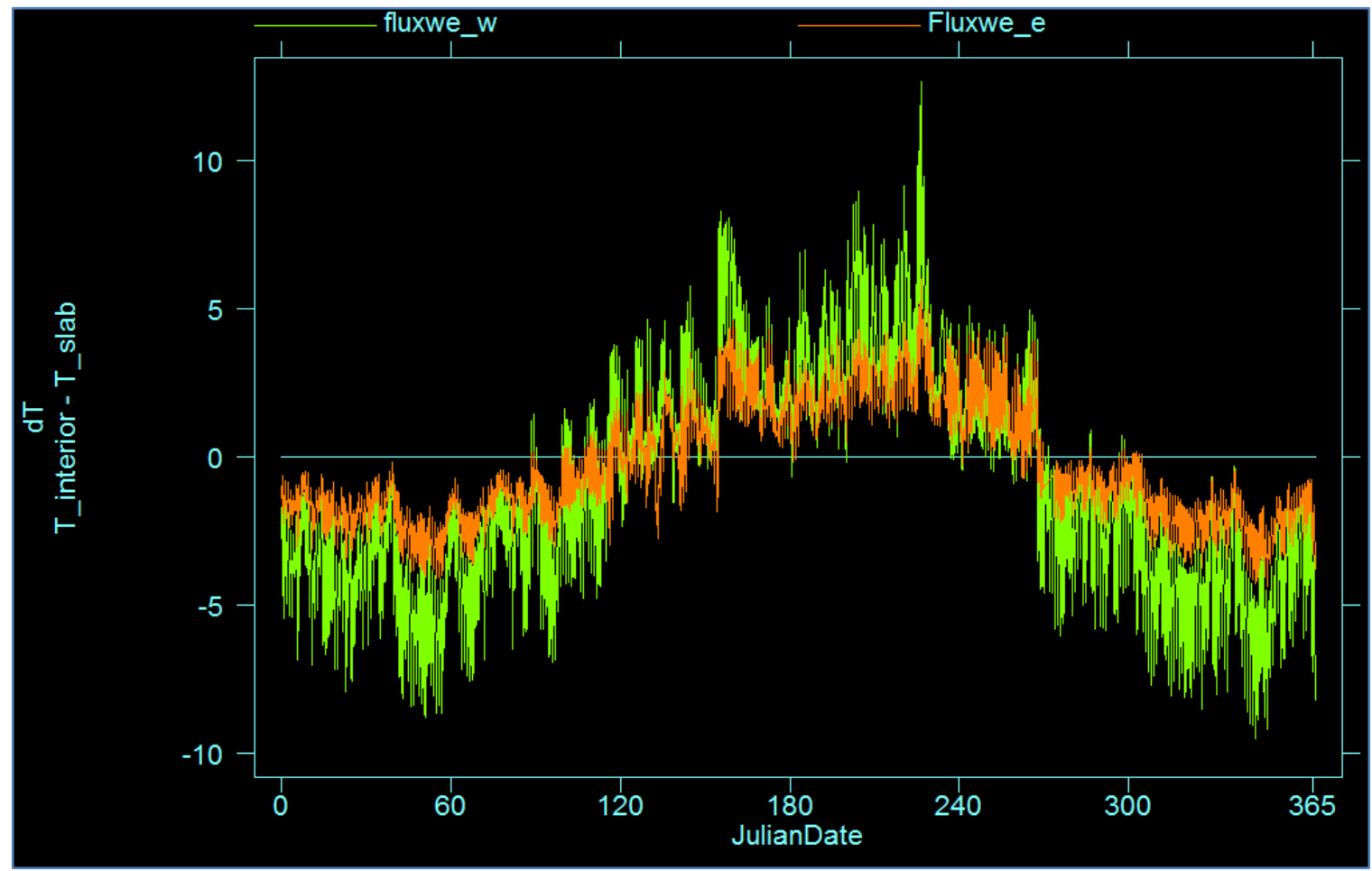

Figure 13. West edge surrogate fluxes $(\Delta T)$ : Green (west exposed), brown (east carpeted)

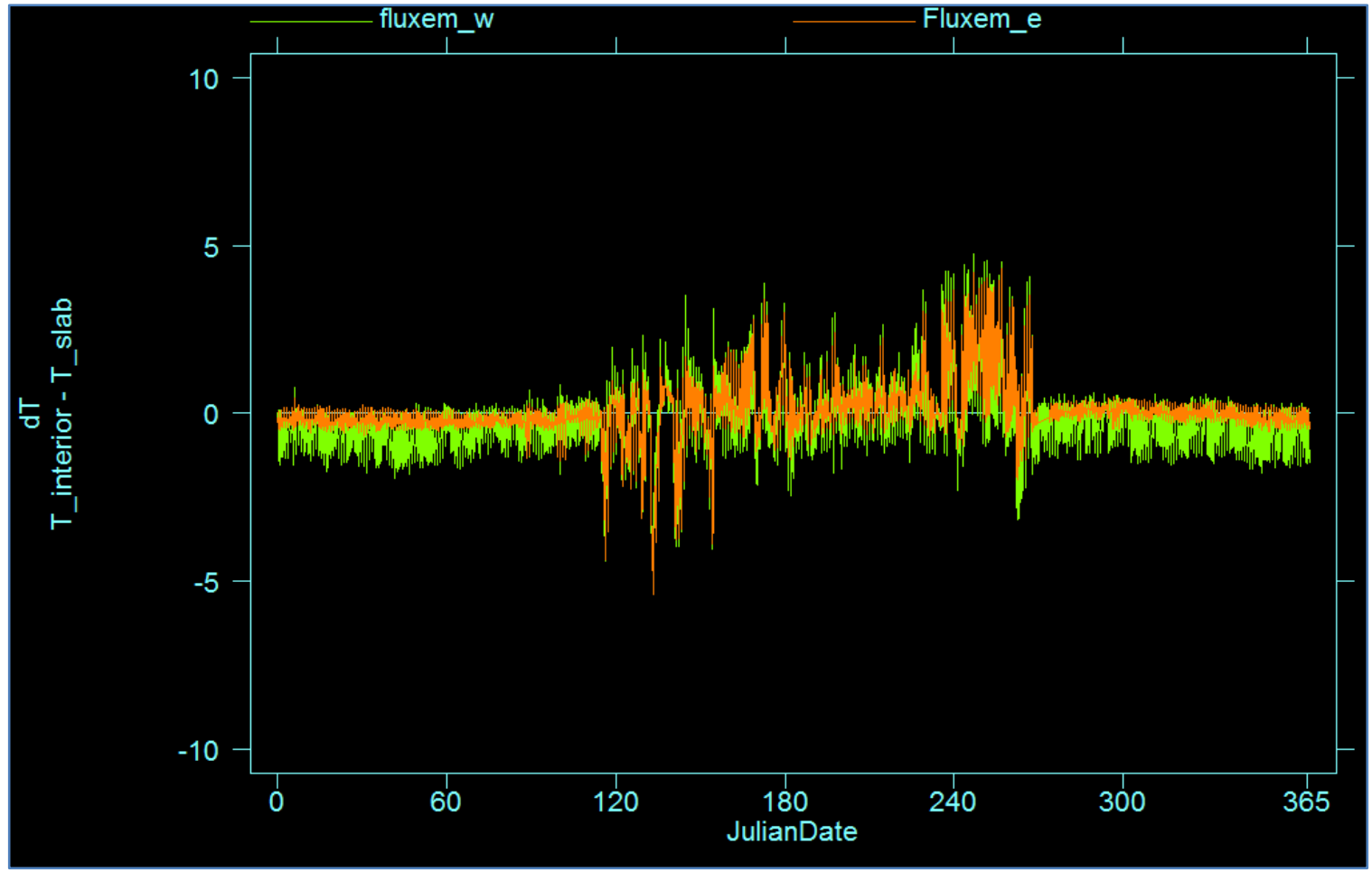

Figure 14. East midpoint surrogate fluxes $(\Delta T)$ : Green (west exposed), brown (east carpeted) 


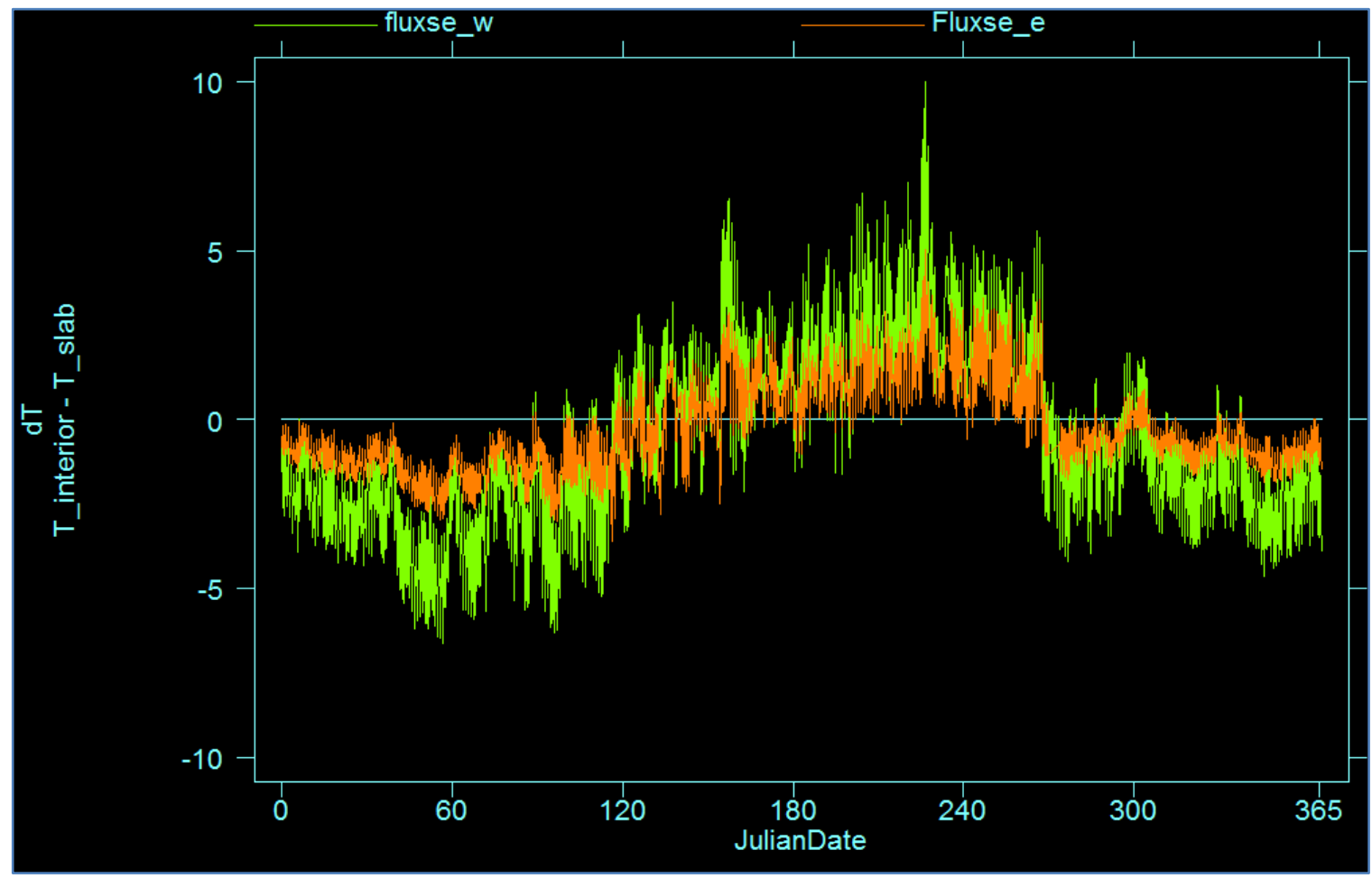

Figure 15. South edge surrogate fluxes $(\Delta T)$ : Green (west exposed), brown (east carpeted)

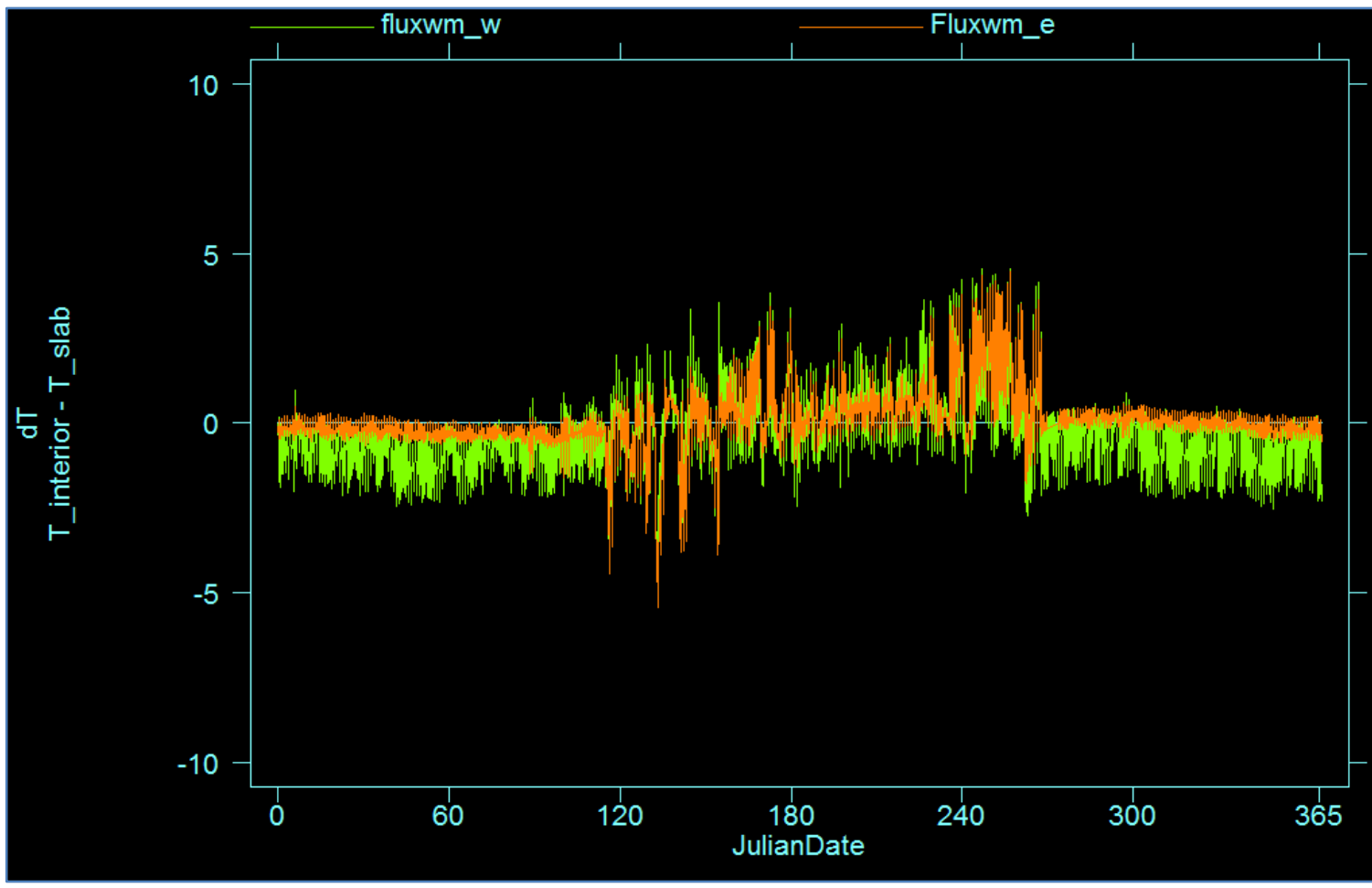

Figure 16. West midpoint surrogate fluxes $(\Delta T)$ : Green (west exposed), brown (east carpeted) 


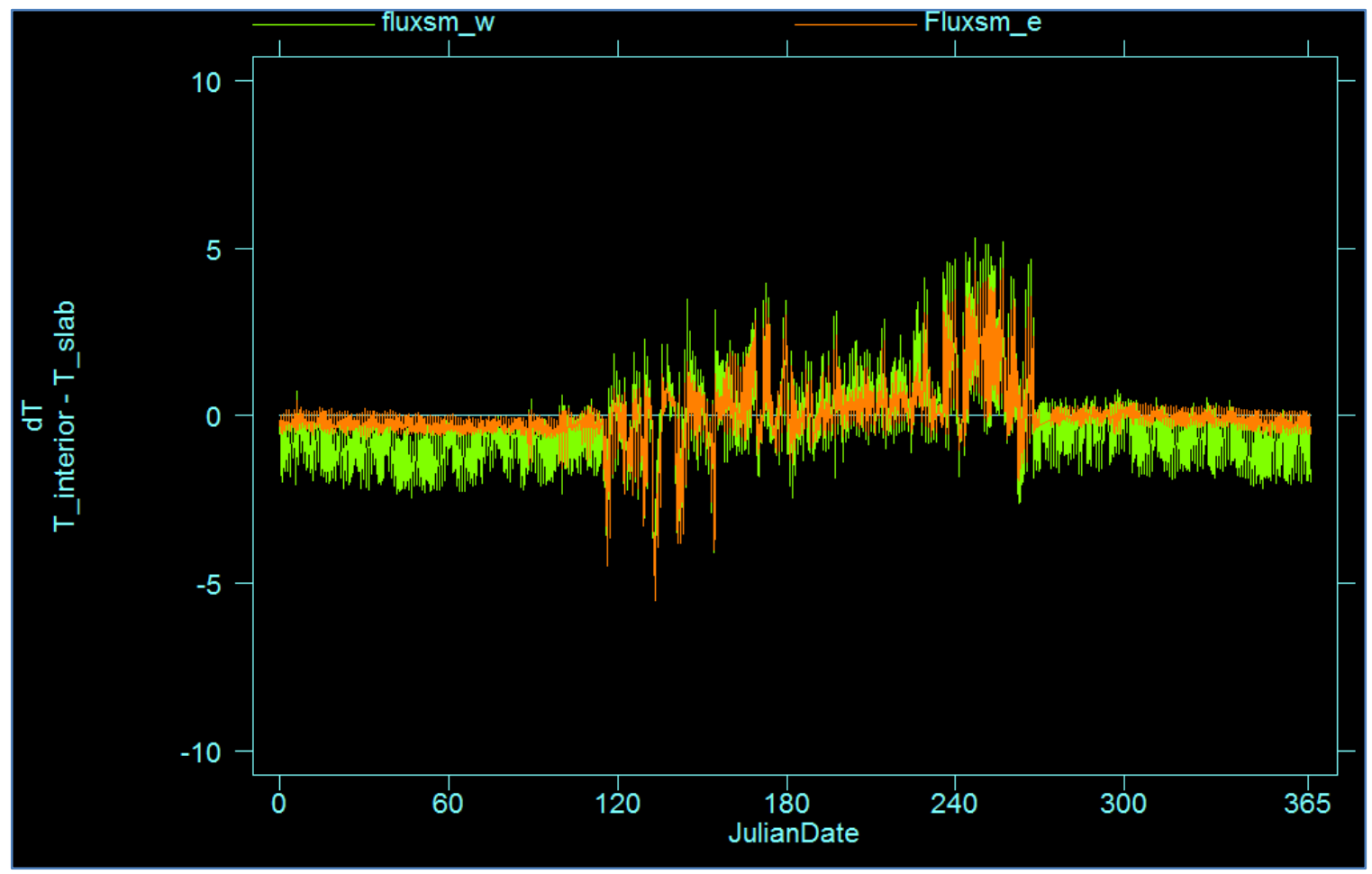

Figure 17. South midpoint surrogate fluxes $(\Delta T)$ : Green (west exposed), brown (east carpeted)

Evaluating the above surrogate flux data each month yields the results shown in Table 6 . For reference, we again provide the slab surface temperature location as Figure 18.

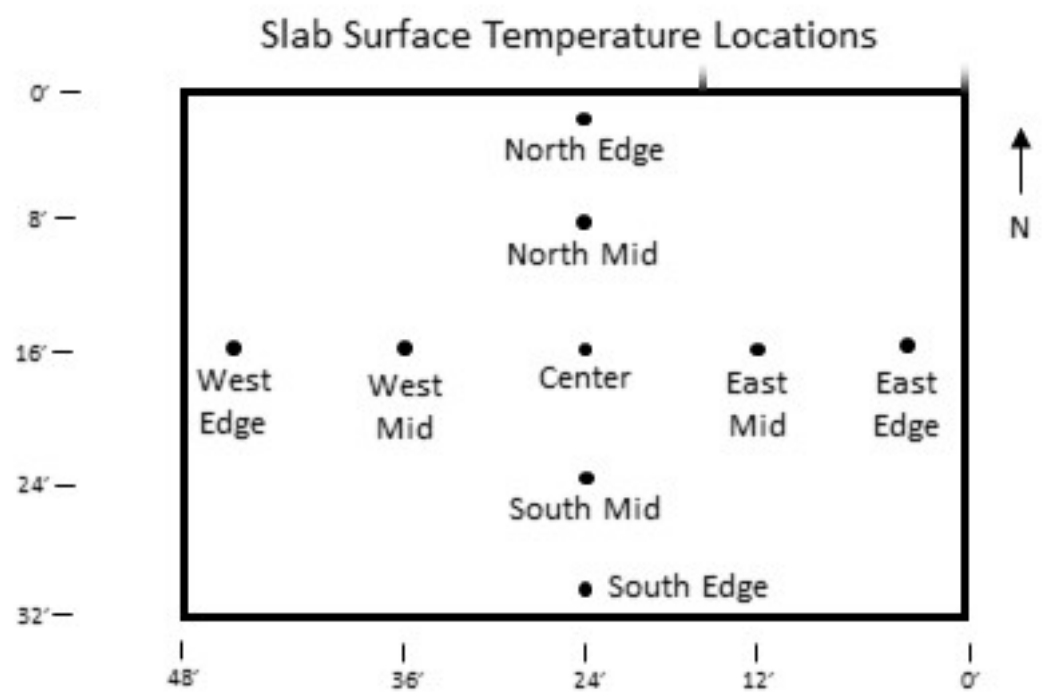

Figure 18. Slab surface temperature locations 
Table 6. Monthly Surrogate Heat Flux Data $\Delta \mathrm{T}\left({ }^{\circ} \mathrm{F}\right)$

\begin{tabular}{|c|c|c|c|c|c|c|c|c|c|}
\hline \multicolumn{10}{|c|}{ West-Exposed Slab (Uncarpeted) } \\
\hline Month & NE & SE & WE & EE & CNT & NM & SM & WM & EM \\
\hline Jan & - & -2.38 & -3.83 & -4.06 & -1.04 & - & -0.94 & -0.79 & -0.62 \\
\hline Feb & -2.84 & -3.64 & -4.63 & -4.21 & -1.37 & -1.69 & -1.22 & -1.10 & -0.79 \\
\hline Mar & -1.56 & -2.82 & -3.18 & -2.44 & -0.97 & -1.11 & -0.95 & -0.79 & -0.50 \\
\hline Apr & -1.14 & -2.31 & -1.61 & -0.65 & -0.71 & -0.44 & -0.85 & -0.76 & -0.44 \\
\hline May & 2.99 & 0.39 & 1.41 & 1.61 & -0.35 & 0.21 & -0.45 & -0.39 & -0.43 \\
\hline June & 4.46 & 1.62 & 3.05 & 3.34 & 0.33 & 1.03 & 0.29 & 0.30 & 0.13 \\
\hline July & 5.22 & 2.33 & 3.77 & 4.10 & 0.26 & 1.06 & 0.26 & 0.25 & 0.00 \\
\hline Aug & 5.52 & 3.19 & 3.73 & 6.09 & 0.17 & 1.47 & 0.88 & 0.75 & 0.47 \\
\hline Sept & 3.06 & 1.46 & 0.87 & 1.12 & 0.71 & 1.02 & 0.92 & 0.61 & 0.51 \\
\hline Oct & -0.51 & -0.89 & -2.42 & -1.65 & -0.45 & -0.60 & -0.35 & -0.44 & -0.25 \\
\hline Nov & -2.61 & -1.72 & -4.62 & -2.94 & -0.83 & -1.23 & -0.66 & -0.82 & -0.45 \\
\hline Dec & -3.12 & -2.28 & -4.46 & -4.06 & -1.01 & -1.50 & -0.82 & -0.92 & -0.61 \\
\hline
\end{tabular}

\section{East-Carpeted}

$\begin{array}{lrrrrrrrrr}\text { Jan } & - & -1.05 & -1.78 & -2.41 & -0.23 & - & -0.22 & -0.16 & -0.26 \\ \text { Feb } & -1.06 & -1.63 & -2.30 & -2.40 & 0.25 & -0.13 & -0.51 & -0.46 & -0.25 \\ \text { Mar } & -0.61 & -1.37 & -1.68 & -1.47 & 0.08 & -0.14 & -0.34 & -0.33 & -0.24 \\ \text { Apr } & 0.72 & -1.36 & -0.87 & -0.38 & 0.64 & -0.14 & -0.44 & -0.45 & -0.29 \\ \text { May } & 1.68 & -0.13 & 0.54 & 0.68 & 0.93 & -0.10 & -0.53 & -0.51 & -0.44 \\ \text { June } & 3.05 & 0.99 & 2.03 & 2.00 & 1.22 & 0.96 & 0.38 & 0.45 & 0.40 \\ \text { July } & 3.28 & 1.19 & 2.27 & 2.24 & 0.52 & 0.77 & 0.17 & 0.29 & 0.17 \\ \text { Aug } & 3.73 & 1.78 & 2.54 & 2.55 & 1.17 & 1.29 & 0.66 & 0.76 & 0.61 \\ \text { Sept } & 2.80 & 1.27 & 1.54 & 1.50 & 1.23 & 1.77 & 1.23 & 1.33 & 1.17 \\ \text { Oct } & 0.23 & -0.48 & -0.95 & -0.81 & 0.25 & 0.39 & 0.01 & 0.15 & 0.08 \\ \text { Nov } & -0.66 & -0.71 & -2.03 & -1.54 & -0.76 & 0.24 & -0.04 & 0.03 & 0.02 \\ \text { Dec } & -1.17 & -1.03 & -2.31 & -2.26 & -0.28 & -0.01 & -0.20 & -0.16 & -0.14\end{array}$

— Data missing

$$
\begin{aligned}
& \text { Heating } \\
& \text { Cooling } \\
& \text { Floating }
\end{aligned}
$$

Evaluating both the graphic and tabular surrogate heat flux data reveals the following:

- Heating: Winter heat losses (orange tint) are seen at all measurement points; greatest at the edges. Heat gains and losses are lowest at the slab floor center at the mid points between the center and edges.

- Heating: Carpet attenuates winter heat losses seen relative to the unsurfaced slab. 
- Cooling: Heat gains, adding to cooling load, are seen across the slab in summer under cooling (blue tint) and are also greatest at the edges - particularly the north edge by the unconditioned garage (which becomes very hot in summer).

- Cooling: Heat gains to the interior is summer are reduced by the carpet.

- Floating conditions: Heat fluxes change (including flow direction) over the seasons, particularly at the slab center and midpoints.

\subsection{Heating Results}

For heating, we examined 14 days over the year where the outdoor temperature was less than $55^{\circ} \mathrm{F}$, which have been clearly shown to be heating periods in Florida homes (Sutherland et al. 2016).

For the heating period, we found a $4.3 \%$ difference in energy use for days colder than $55^{\circ} \mathrm{F}$ with the carpeted east building showing lower energy consumption by approximately $0.65 \pm 0.15$ $\mathrm{kWh} / \mathrm{d}$. Using resistance heat, consumption was $15.16 \mathrm{kWh} / \mathrm{d}$ in the carpeted east building and $15.81 \mathrm{kWh} / \mathrm{d}$ for the west building with the exposed slab. It should be pointed out that while this difference was measureable and statistically significant, the quantity is a very small amount of energy in absolute terms. Relative humidities in the two buildings were virtually identical and statistically indistinguishable. ${ }^{9}$

Table 7. Interior Conditions and Space Heating Energy Use for the 14 Days of Heating Below $55^{\circ} \mathrm{F}$

\begin{tabular}{|c|c|c|c|c|c|c|c|c|}
\hline & $\begin{array}{c}\text { East } \\
\text { (Carpeted) }\end{array}$ & $\begin{array}{c}\text { West } \\
\text { (Exposed } \\
\text { Slab) }\end{array}$ & Difference & $\begin{array}{c}\% \\
\text { Difference }\end{array}$ & $\begin{array}{l}\text { Standard } \\
\text { Deviation }\end{array}$ & $\begin{array}{l}\text { Standard } \\
\text { Error }\end{array}$ & $\begin{array}{c}t \text {-stat } \\
\text { (df }=313)\end{array}$ & $p$-value \\
\hline $\begin{array}{l}\text { Interior Temp } \\
{\left[{ }^{\circ} \mathrm{F}\right]}\end{array}$ & 74.99 & 74.49 & 0.50 & & 1.27 & 0.07 & 6.95 & $<0.001$ \\
\hline Interior RH [\%] & 39.16 & 39.20 & -0.04 & & 7.64 & 0.43 & -0.09 & 0.927 \\
\hline $\begin{array}{l}\text { Interior Dew } \\
\left.\text { Point (DP) [ }{ }^{\circ} \mathrm{F}\right]\end{array}$ & 47.86 & 47.45 & 0.42 & & 2.55 & 0.14 & 2.89 & 0.004 \\
\hline $\begin{array}{l}\text { Air Handling Unit } \\
\text { (AHU) Energy } \\
\text { Use [kWh/d] }\end{array}$ & 15.16 & 15.81 & -0.65 & $-4.3 \%$ & 2.65 & 0.15 & -4.35 & $<0.001$ \\
\hline
\end{tabular}

For the four days where the outdoor temperature was below $50^{\circ} \mathrm{F}$ and greater heating would be required, the heating consumption was $22.52 \mathrm{kWh} / \mathrm{d}$ in the carpeted east building and 23.46 $\mathrm{kWh} / \mathrm{d}$ in the west building (a relatively small difference of $0.93 \pm 0.31 \mathrm{kWh}$ or $4.1 \%$ ). Also, even though the thermostats were set similarly to $73^{\circ} \mathrm{F}$, the interior temperature tended to be about $0.50^{\circ} \mathrm{F}$ warmer in the carpeted east building (floating above the thermostat cut-in point) very possibly due to the floor covering itself. Note that the thermostats do not maintain interior temperatures that are closer than $1^{\circ} \mathrm{F}$ due to their conventional mode of operation, although null testing in a similar thermal configuration showed nearly identical thermal performance (Vieira and Sherwin 2012).

Both thermostats were set to $73^{\circ} \mathrm{F}$, although the buildings tended to float at different temperatures during the heating period above. Given the comparability of the two buildings

\footnotetext{
${ }^{9}$ The statistics for standard error, t-statistic, and p-values in Table 4-10 refer to the measured differences between the east and west units measured relative to the characteristic in question.
} 
during null tests without space conditioning, it seems likely this was due to the carpet in the east building. It is noted that although the carpeted east building floated at a higher temperature, the carpeted building actually also showed lower measured space heating. Both homes use identical heating systems with resistance electricity circulated to the space by a blower. As the carpeted building floated at a warmer temperature while also using 4\% less space heating, this would indicate that this estimate of the savings is conservative. Relative humidities and dew points in the two buildings were virtually identical and statistically indistinguishable.

Table 8. Interior Conditions and Space Heating Energy Use during the 4 Days of Heating Below $50^{\circ} \mathrm{F}$

\begin{tabular}{|c|c|c|c|c|c|c|c|c|}
\hline & $\begin{array}{c}\text { East } \\
\text { (Carpeted) }\end{array}$ & $\begin{array}{c}\text { West } \\
\text { (Exposed } \\
\text { Slab) }\end{array}$ & Difference & $\begin{array}{c}\% \\
\text { Difference }\end{array}$ & $\begin{array}{l}\text { Standard } \\
\text { Deviation }\end{array}$ & $\begin{array}{l}\text { Standard } \\
\text { Error }\end{array}$ & $\begin{array}{c}\text { t-stat } \\
\text { (df=95) }\end{array}$ & p-value \\
\hline Interior Temp [ $\left.{ }^{\circ} \mathrm{F}\right]$ & 75.43 & 74.91 & 0.52 & & 1.27 & 0.13 & 4.00 & $<0.001$ \\
\hline Interior RH [\%] & 30.16 & 30.31 & -0.15 & & 7.64 & 0.78 & -0.20 & 0.844 \\
\hline Interior DP $\left[{ }^{\circ} \mathrm{F}\right]$ & 41.45 & 41.13 & 0.33 & & 2.55 & 0.26 & 1.27 & 0.208 \\
\hline $\begin{array}{l}\text { AHU Energy Use } \\
\text { [kWh/d] }\end{array}$ & 22.52 & 23.46 & -0.93 & $-4.1 \%$ & 3.06 & 0.31 & -2.99 & 0.004 \\
\hline
\end{tabular}

On the peak heating day of February 20, 2015, the carpeted east building used less space heating at $28.8 \mathrm{kWh}$ versus $29.6 \mathrm{kWh}$ for the uncarpeted west building - although given that this is a single day, the data for the four coldest days shown in Table 9 may be considered more representative of performance under colder conditions. The air temperature in the carpeted east building was also approximately $0.5^{\circ} \mathrm{F}$ warmer than the west building.

Table 9. Interior Conditions and Space Heating Energy Use for Peak Heating Day, February 20, 2015

\begin{tabular}{|c|c|c|c|c|c|c|c|c|}
\hline & $\begin{array}{c}\text { East } \\
\text { (Carpeted) }\end{array}$ & $\begin{array}{l}\text { West } \\
\text { (Exposed } \\
\text { Slab) }\end{array}$ & Difference & $\begin{array}{c}\% \\
\text { Difference }\end{array}$ & $\begin{array}{l}\text { Standard } \\
\text { Deviation }\end{array}$ & $\begin{array}{l}\text { Standard } \\
\text { Error }\end{array}$ & $\begin{array}{c}\text { t-stat } \\
(\mathrm{df}=23)\end{array}$ & $p$-value \\
\hline Interior Temp $\left[{ }^{\circ} \mathrm{F}\right]$ & 75.93 & 75.38 & 0.55 & & 1.27 & 0.26 & 2.12 & 0.045 \\
\hline Interior RH [\%] & 25.16 & 25.49 & -0.34 & & 7.64 & 1.56 & -0.22 & 0.831 \\
\hline Interior DP [ $\left.{ }^{\circ} \mathrm{F}\right]$ & 37.59 & 37.43 & 0.16 & & 2.55 & 0.52 & 0.32 & 0.755 \\
\hline $\begin{array}{l}\text { AHU Energy Use } \\
{[\mathrm{kWh} / \mathrm{d}]}\end{array}$ & 28.83 & 29.55 & -0.73 & $-2.5 \%$ & 4.89 & 1.00 & -0.73 & 0.475 \\
\hline
\end{tabular}

Thermal contour plots of heating data (Figure 19) show heat loss to the ground, with particularly striking changes seen from the slab edge. Note that these changes at slab edge are not an artifact of sensor space as the temperatures measured at the slab edge are $1 \mathrm{ft}$ inside the interior of the wall while the estimate outside the slab edge is only $2 \mathrm{ft}$ from the wall. ${ }^{10}$ While this may not be an ideal resolution for examining this difference, the very large change in the heat flow contours at the slab edge shown in the plots is real, showing that the heat flows from the slab interior and the slab's interruption of the effects of solar radiation and rainfall (both factors) combine to

\footnotetext{
${ }^{10}$ The contour plots shown should be considered approximate. While spacing of $2 \mathrm{ft}$ or less would provide much more precise indication of thermal anomalies and intervals, it was decided that such a representation as that made in the report must be used to help the reader visually understand the relationship of the eight odd measurement points being represented for each slab floor.
} 
significantly alter the thermal environment underneath the slab floor. In any case, this finding is in agreement with experimental measurements of slab floors stretching back to work done post World War II by the University of Illinois (Bareither et al. 1948). The plots show the solar heating of the soil surface outside the building profile, as well as the profile across the building interior, the ground temperatures down to $10 \mathrm{ft}$. Note the very different thermal domains under and outside the building in winter.

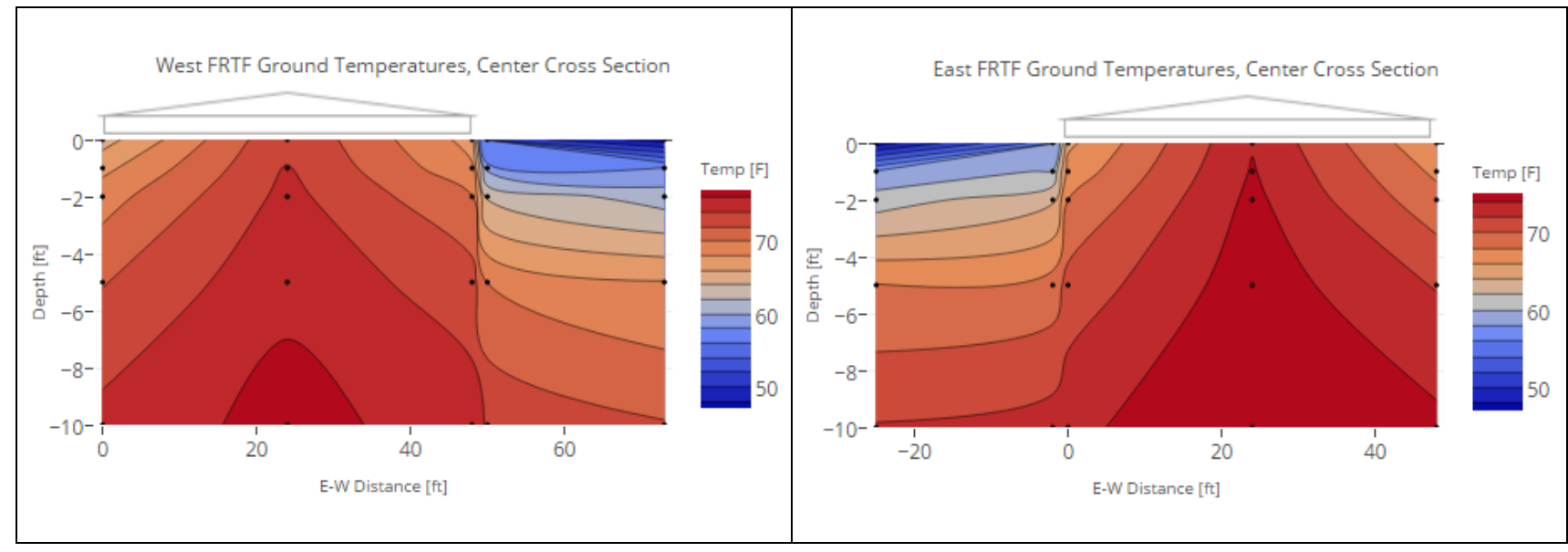

Figure 19. Contours of slab \& ground thermal performance during peak winter day: Feb 20, 2015. Note the end points of the contour plots are actually 32.5 feet from end of the structures and have been shortened to simplify display.

A fundamental finding for Florida is that homes with carpeted floors tend to use $4 \%$ less heating than those without carpet (e.g., fully tiled). From a heat-transfer standpoint, this result is not surprising because the carpet would tend to insulate the house interior air node from the slab floor. These differences are large enough to appear robust, and even though the sample days were quite limited by Florida's short heating season, the results are statistically significant.

To help visualize the heating impacts, we conducted time-lapse thermographs of the southwest corner of the FRTF floor on one of the coldest nights of the year in 2013. Figure 20 shows the setup, along with the visual spectrum of the area of the floor captured. 


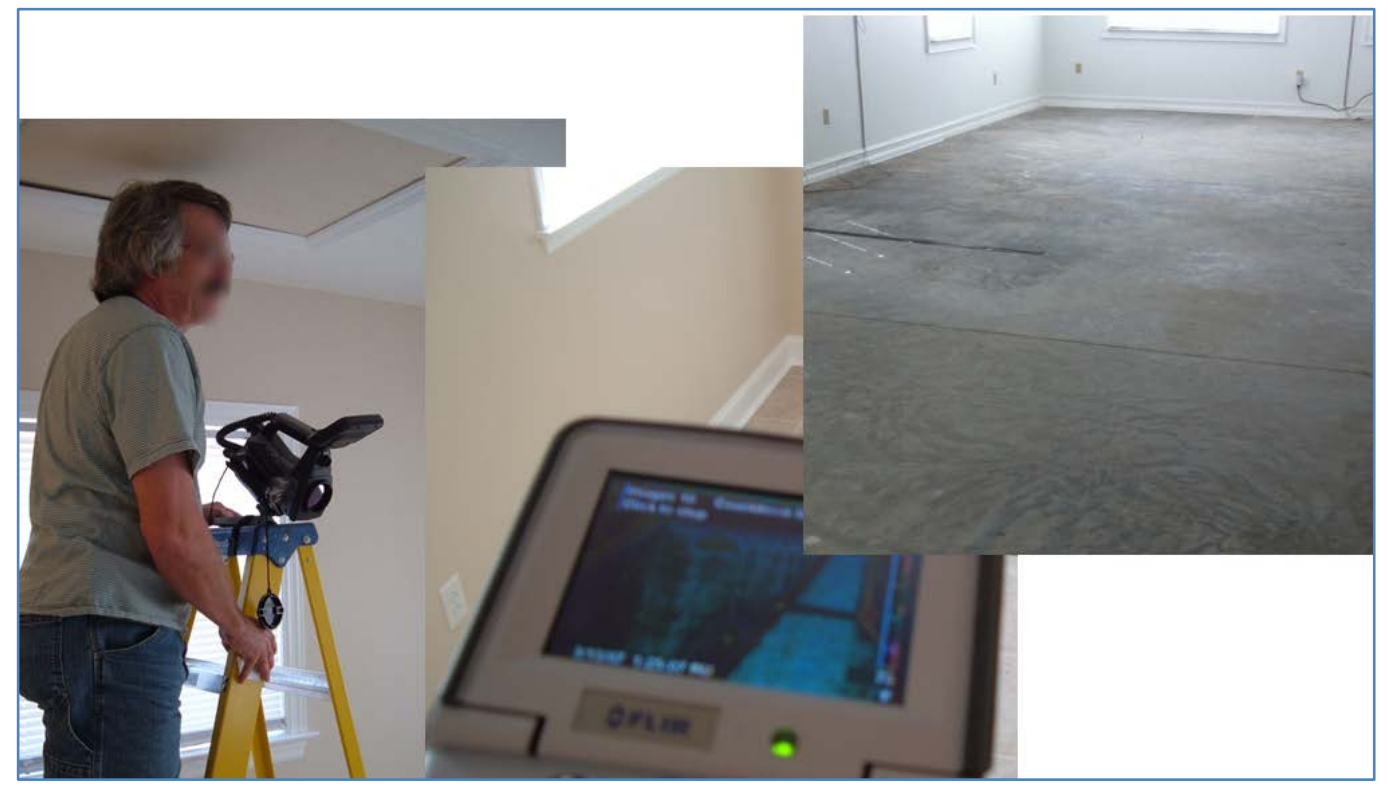

Figure 20. Setup for time lapse thermography of uncovered west building slab floor on the coldest night of 2013

Below, we show stills at 2-hr intervals from the resulting thermographs of the floor and south and west wall sections. Considerable detail can be seen in the images, clearly showing that while the slab is warmer toward the center, there are considerable heat losses on the edges of the slab floor. On each image is shown the time as well as the outdoor temperature on February 17, 2013. Color is proportional to temperature. The flashes of heat shown on the slab surface come from the cycling on of the space heating system. The heat loss/gain of the south-facing window can also be seen reflected on the floor. The heat losses from the slab edge in the early morning are clearly visible. 


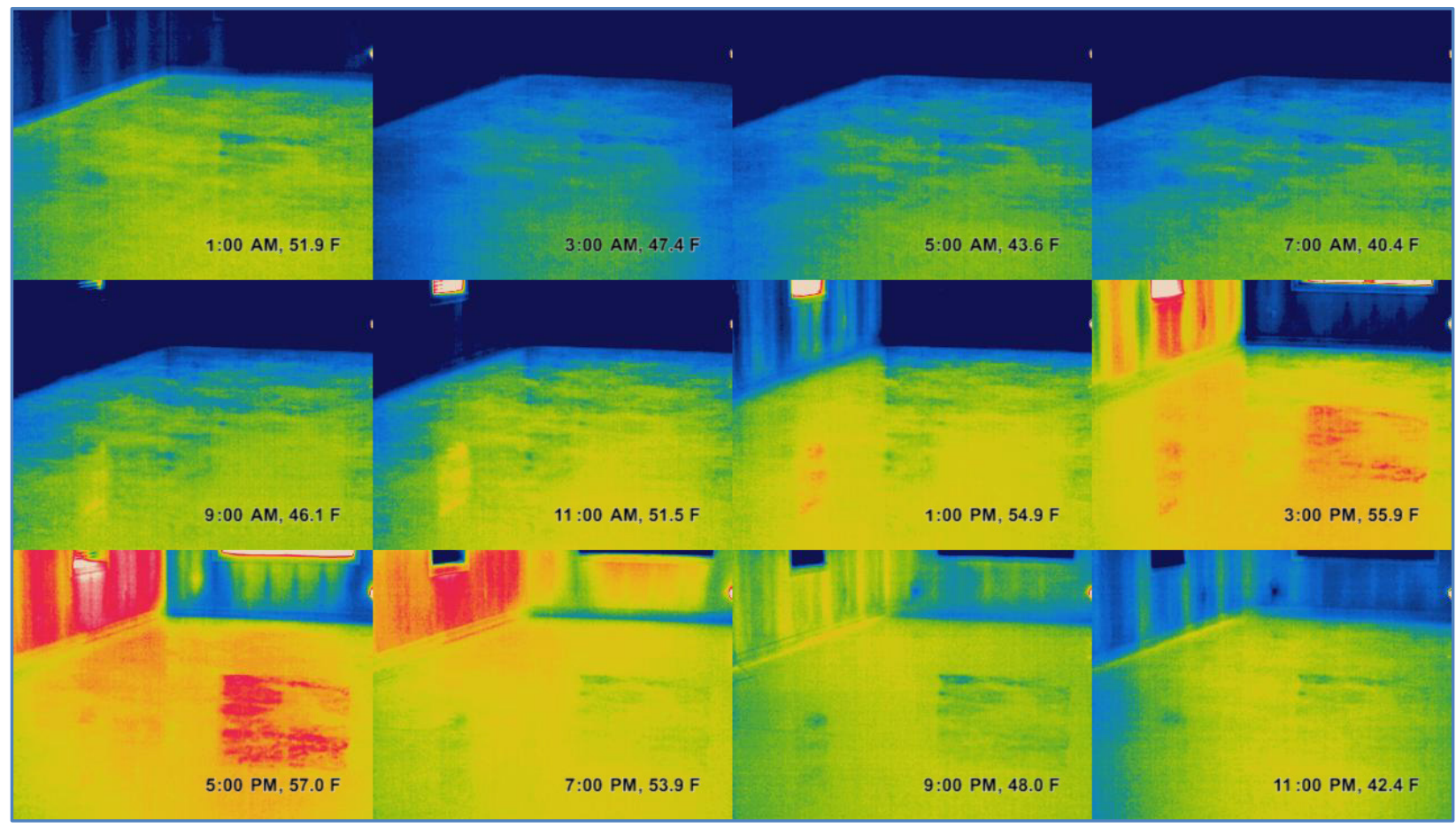

Figure 21. Time lapse thermography of southwest slab floor on west building interior on February 17,2013 . Note edge losses are clearly apparent by dark blue regions during evening hours.

\subsection{Performance Under Floating Conditions}

We evaluated the performance of the two side-by-side buildings during the fall and spring for a period of 55 days when the HVAC system was inactive. In the spring period, the buildings were left in heating mode when there was no heating load to allow the buildings to float above the summer thermostat set point.

Table 10. Interior Conditions for 55 Days of Floating Conditions in Fall and Spring

\begin{tabular}{lccccccc}
\hline & $\begin{array}{c}\text { East } \\
\text { (Carpeted) }\end{array}$ & $\begin{array}{c}\text { West } \\
\text { (Exposed } \\
\text { Slab) }\end{array}$ & Difference & $\begin{array}{c}\text { Standard } \\
\text { Deviation }\end{array}$ & $\begin{array}{c}\text { Standard } \\
\text { Error }\end{array}$ & $\begin{array}{c}\text { t-stat } \\
\text { (df=1182) }\end{array}$ & p-value \\
\hline Interior Temp [ $\left.{ }^{\circ} \mathrm{F}\right]$ & 77.89 & 77.17 & 0.72 & 1.57 & 0.05 & 15.82 & $<0.001$ \\
\hline Interior RH [\%] & 62.81 & 63.32 & -0.51 & 7.64 & 0.22 & -2.30 & 0.022 \\
Interior DP [ $\left.{ }^{\circ} \mathrm{F}\right]$ & 64.00 & 63.52 & 0.48 & 2.55 & 0.07 & 6.48 & $<0.001$ \\
\hline
\end{tabular}

During this 55-day spring and fall period, the carpeted east building ran $0.72 \pm 0.5^{\circ} \mathrm{F}$ warmer than the uncarpeted west building $\left(77.89^{\circ} \mathrm{F}\right.$ versus $\left.77.17^{\circ} \mathrm{F}\right)$. Interior relative humidity was slightly higher in the carpeted east building $(0.51 \pm 0.22 \%)$ and the dew point in the carpeted east building was $0.48 \pm 0.07^{\circ} \mathrm{F}$ higher. ${ }^{11}$

\footnotetext{
${ }^{11}$ Uncertainties estimated considering stated sensor accuracy. For multiple measurement points, such as dew point, the estimate assumes stated accuracies of temperature and relative humidity measurement with errors propagated considering the root-mean-square error (RMSE) of the resulting error stream.
} 
The interior temperature profile for a springtime floating period, March 13-24, 2015, shows a clear rise in interior temperature in the carpeted building as shown in Figure 22. The temperature of the carpeted home averaged more than $86^{\circ} \mathrm{F}$ in the afternoon whereas the exposed slab home kept the peak average around $84^{\circ} \mathrm{F}$. (The undulations in the temperature data in the pre- and postperiods comes from natural on-off cycling of the air-conditioner compressor during the periods.) During such periods in spring while the ground is near its coolest temperatures the exposed slab would provide an advantage.

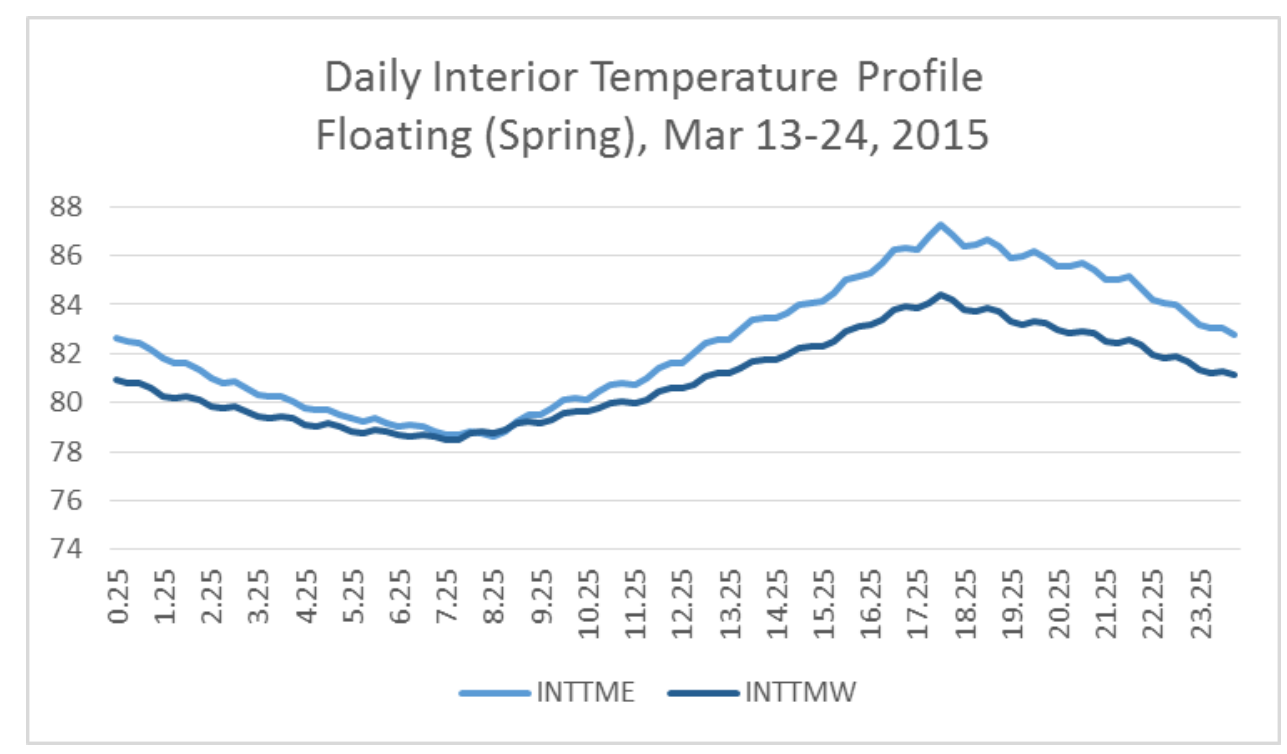

Figure 22. Interior temperatures while floating during a period of warm spring weather, March 13-24, 2015

Thermal contours, shown in Figure 23, for the March 13-24, 2015, period reveal that most of the "free cooling" during spring is actually coming from the slab edge at a depth down to approximately $2 \mathrm{ft}$. We note that the deep-ground temperature is now actually higher than that at shallow depths (as seen in the undisturbed ground temperature profiles). It should also be noted that the magnitude of the temperature differences seen from the slab surface down to the ground at a 10 -ft depth are modest- just over $6^{\circ} \mathrm{F}$. This is quite different from the larger differences seen during the heating periods (Figure 19). 


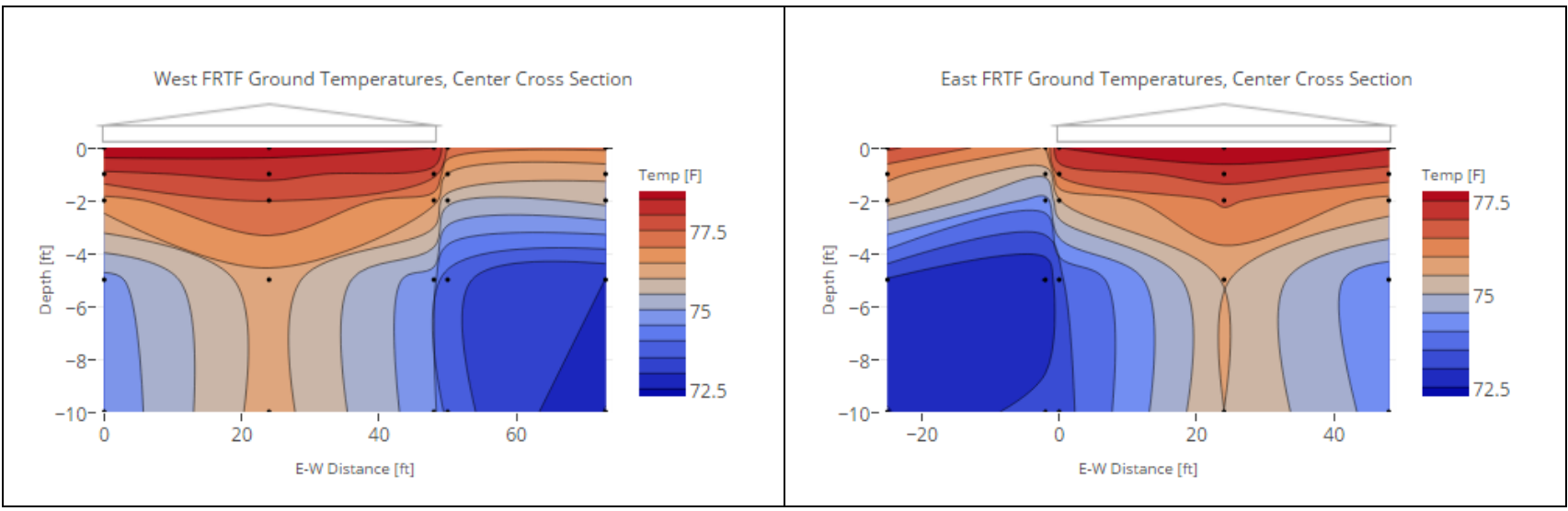

Figure 23. Contours during spring floating condition: Mar 13-24, 2015. Note the end points of the contour plots are actually $\mathbf{3 2 . 5}$ feet from end of the structures and have been shortened to simplify display.

A conclusion from the assessment during this period is that homes with carpeted slab floors in central Florida will tend to run slightly warmer during the floating non-heating, non-cooling season than those with strongly earth-coupled floors that would be similar to the construction in the west building.

\subsection{Light Cooling Period Results}

Periods of light cooling were defined as the 132 days where the average daily dew point temperature was less than $70^{\circ} \mathrm{F}$, but the building still required the air-conditioning system to maintain the interior set point of $77^{\circ} \mathrm{F}$. These cooling energy needs were typically low; however, the uncarpeted west building showed an average measured daily space cooling of $16.94 \mathrm{kWh}$ against $16.64 \mathrm{kWh}$ in the carpeted east building. This results in a small but statistically significant increase in energy use for the carpeted home $(0.29 \pm 0.03 \mathrm{kWh}, 1.7 \%)$. The interior temperature and dew point of the carpeted east home was slightly higher than that of the west home (by $0.19^{\circ} \mathrm{F}$ and $0.25^{\circ} \mathrm{F}$, respectively).

Table 11. Interior Conditions and Space Cooling Energy Use during 132 Days of Light Cooling

\begin{tabular}{|c|c|c|c|c|c|c|c|c|}
\hline & $\begin{array}{c}\text { East } \\
\text { (Carpeted) }\end{array}$ & $\begin{array}{c}\text { West } \\
\text { (Exposed } \\
\text { Slab) }\end{array}$ & Difference & $\begin{array}{c}\% \\
\text { Difference }\end{array}$ & $\begin{array}{l}\text { Standard } \\
\text { Deviation }\end{array}$ & $\begin{array}{l}\text { Standard } \\
\text { Error }\end{array}$ & $\begin{array}{c}\text { t-stat } \\
(\mathrm{df}=2811)\end{array}$ & p-value \\
\hline Interior Temp $\left[{ }^{\circ} \mathrm{F}\right]$ & 75.90 & 75.71 & 0.19 & & 1.27 & 0.02 & 7.80 & $<0.001$ \\
\hline Interior RH [\%] & 49.35 & 49.24 & 0.11 & & 7.64 & 0.14 & 0.76 & 0.446 \\
\hline Interior DP [ $\left.{ }^{\circ} \mathrm{F}\right]$ & 55.44 & 55.19 & 0.25 & & 2.55 & 0.05 & 5.18 & $<0.001$ \\
\hline $\begin{array}{l}\text { AHU Energy Use } \\
\text { [kWh/d] }\end{array}$ & 2.50 & 2.42 & 0.07 & $3.0 \%$ & 1.35 & 0.03 & 2.95 & 0.003 \\
\hline $\begin{array}{l}\text { Compressor Energy } \\
\text { Use }[\mathrm{kWh} / \mathrm{d}]\end{array}$ & 14.44 & 14.22 & 0.22 & $1.5 \%$ & 2.51 & 0.05 & 4.63 & $<0.001$ \\
\hline $\begin{array}{l}\text { Total HVAC Energy } \\
\text { Use [kWh/d] }\end{array}$ & 16.94 & 16.64 & 0.29 & $1.7 \%$ & 1.45 & 0.03 & 10.77 & $<0.001$ \\
\hline
\end{tabular}

Ground thermal performance contours during the continuous light cooling period of October 1930,2014 , reveals that the deep-ground temperature is actually lower than what is being maintained inside. Thus, the greater thermal linkage of the uncarpeted west test building is actually a slight advantage for this period of modest air conditioning. 


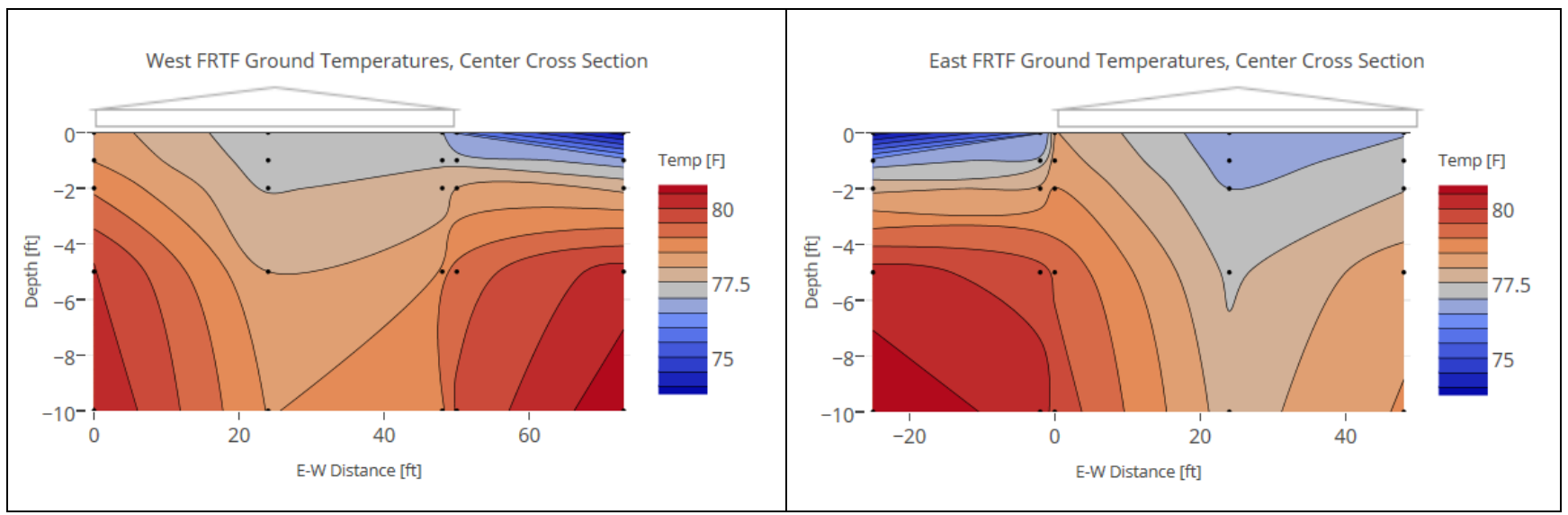

Figure 24. Contours during a light cooling period: October 19-30, 2014. Note the end points of the contour plots are actually $\mathbf{3 2 . 5}$ feet from end of the structures and have been shortened to simplify display.

\subsection{Heavy Cooling Period Results}

During days where the average dew point temperature was greater than $70^{\circ} \mathrm{F}(115$ heavy cooling days), we found that the uncarpeted west building tended to run about $0.35^{\circ} \mathrm{F}$ cooler than the carpeted east building, with a $0.43^{\circ} \mathrm{F}$ lower dew point temperature as well. Cooling energy use in the two homes was nearly identical (28.18 and $28.27 \mathrm{kWh}$ for east and west respectively) and showed no statistically significant difference. This tends to reinforce the idea that for summer conditions in central Florida, the slab floor is only a very minor influence on cooling and at the center of the slab is largely adiabatic with the deep-ground temperature condition and across the rest of the slab floor the temperature differences remain very modest.

Table 12. Interior Conditions and Space Cooling Energy Use during the 115 Days of Heavy Cooling

\begin{tabular}{|c|c|c|c|c|c|c|c|c|}
\hline & $\begin{array}{c}\text { East } \\
\text { (Carpeted) }\end{array}$ & $\begin{array}{c}\text { West } \\
\text { (Exposed } \\
\text { Slab) }\end{array}$ & Difference & $\begin{array}{c}\% \\
\text { Difference }\end{array}$ & $\begin{array}{l}\text { Standard } \\
\text { Deviation }\end{array}$ & $\begin{array}{l}\text { Standard } \\
\text { Error }\end{array}$ & $\begin{array}{c}\text { t-stat } \\
(\mathrm{df}=2724)\end{array}$ & p-value \\
\hline Interior Temp [ $\left.{ }^{\circ} \mathrm{F}\right]$ & 75.88 & 75.52 & 0.35 & & 1.27 & 0.02 & 14.50 & $<0.001$ \\
\hline Interior RH [\%] & 47.29 & 47.13 & 0.16 & & 7.64 & 0.15 & 1.07 & 0.285 \\
\hline Interior DP $\left[{ }^{\circ} \mathrm{F}\right]$ & 54.34 & 53.91 & 0.43 & & 2.55 & 0.05 & 8.78 & $<0.001$ \\
\hline $\begin{array}{l}\text { AHU Energy Use } \\
{[\mathrm{kWh} / \mathrm{d}]}\end{array}$ & 3.10 & 3.01 & 0.09 & $3.0 \%$ & 0.39 & 0.01 & 12.37 & $<0.001$ \\
\hline $\begin{array}{l}\text { Compressor Energy } \\
\text { Use [kWh/d] }\end{array}$ & 25.08 & 25.26 & -0.19 & $-0.7 \%$ & 2.92 & 0.06 & -3.33 & $<0.001$ \\
\hline $\begin{array}{l}\text { Total HVAC Energy } \\
\text { Use [kWh/d] }\end{array}$ & 28.18 & 28.27 & -0.09 & $-0.3 \%$ & 2.94 & 0.06 & -1.67 & 0.094 \\
\hline
\end{tabular}

During an extended maximum cooling period, June 13-28, 2015, where the ambient temperature averaged $81.7^{\circ} \mathrm{F}$ compared to the overall heavy cooling period ambient temperature of $80.2^{\circ} \mathrm{F}$, the carpeted building showed a significant, $0.73 \pm 0.15 \mathrm{kWh}(2.1 \%)$, decrease in daily cooling energy. This supports the idea that carpet helps to control slab edge heat gains under very hot weather conditions and was reinforced by time lapse thermography taken of the interior of the uncarpeted west building over a series of cooling days that showed heat gain from the slab edge. 
Table 13. Interior Conditions and Space Cooling Energy Use during an Extended Heavy Cooling Period, June 13-28, 2015

\begin{tabular}{lcccccccc}
\hline & $\begin{array}{c}\text { East } \\
\text { (Carpeted) }\end{array}$ & $\begin{array}{c}\text { West } \\
\text { (Exposed } \\
\text { Slab) }\end{array}$ & Difference & $\begin{array}{c}\text { \% } \\
\text { Difference }\end{array}$ & $\begin{array}{c}\text { Standard } \\
\text { Deviation }\end{array}$ & $\begin{array}{c}\text { Standard } \\
\text { Error }\end{array}$ & $\begin{array}{c}\text { t-stat } \\
\text { (df=383) }\end{array}$ & p-value \\
\hline Interior Temp [ ${ }^{\circ}$ F] & 75.68 & 75.21 & 0.47 & & 1.27 & 0.06 & 7.23 & $<0.001$ \\
\hline Interior RH [\%] & 45.76 & 44.96 & 0.81 & & 7.64 & 0.39 & 2.08 & 0.039 \\
\hline $\begin{array}{l}\text { Interior DP [ }{ }^{\circ} \text { F] } \\
\begin{array}{l}\text { AHU Energy Use } \\
\text { [kWh/d] }\end{array}\end{array}$ & 53.28 & 52.38 & 0.91 & & 2.55 & 0.13 & 6.98 & $<0.001$ \\
$\begin{array}{l}\text { Compressor Energy } \\
\text { Use [kWh/d] }\end{array}$ & 3.59 & 3.46 & 0.14 & $3.8 \%$ & 0.45 & 0.02 & 6.00 & $<0.001$ \\
$\begin{array}{l}\text { Total HWAC Energy } \\
\text { Use [kWh/d] }\end{array}$ & 34.03 & 34.76 & -0.73 & $-2.1 \%$ & 2.95 & 0.15 & -4.84 & $<0.001$ \\
\hline
\end{tabular}

Thermal performance contours during the June 13-28, 2015, period (Figure 25) show greatest thermal gains from the slab edge.

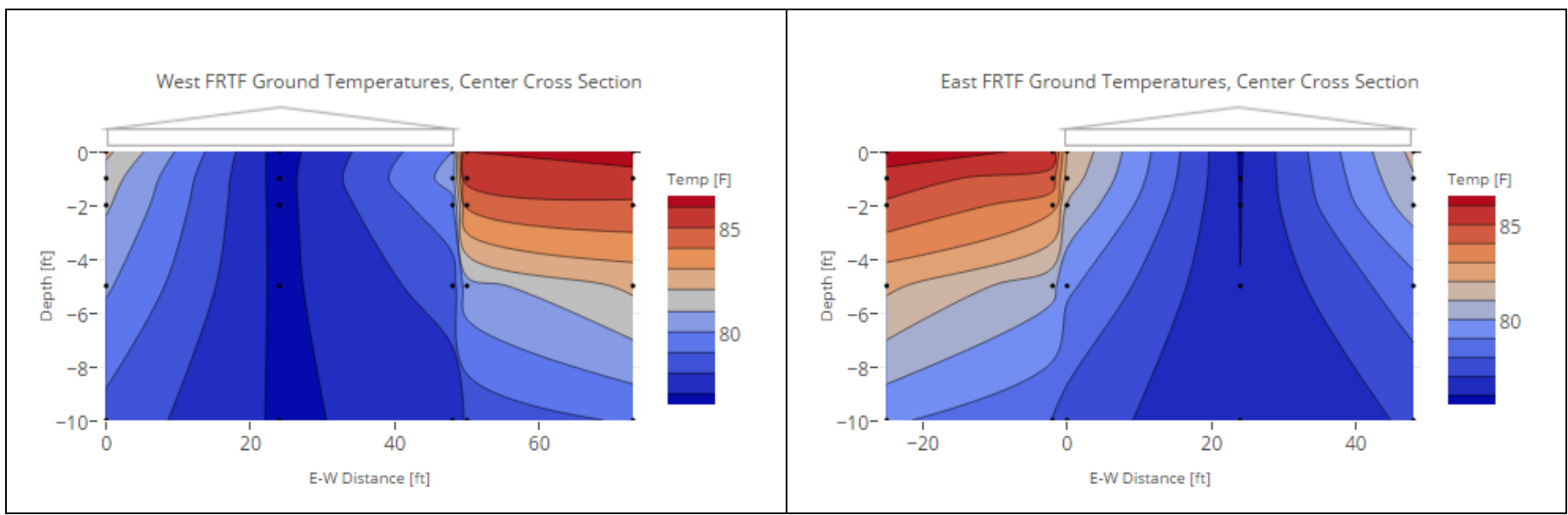

Figure 25. Contours during an extended period of heavy cooling: June 13-28th, 2015. Note the end points of the contour plots are actually 32.5 feet from end of the structures and have been shortened to simplify display. 


\section{Comparison to Simulation Models}

In 1988 a detailed simulation exercise, undertaken by DOE and reported in the Building Foundation Handbook (Labs et al. 1988), included predicted energy use impacts in hot climates. The work used a below-grade simulation model developed and validated at the Underground Space Center at the University of Minnesota. This model created a 2-D finite difference heat conduction program based on the Pantankar-Spalding approach that created fluxes that were then passed to a residential energy simulation for the overall building using the DOE-2 simulation. Relevant to this measurement, within the work, cases were evaluated for Miami, Florida, for a slab-on-grade floor. Miami's climate is quite similar to that in central Florida. This is particularly true given the warmer weather data seen in newer TMY3 weather data for Orlando compared to the 1981 vintage weather data used to drive the simulations for the Handbook analysis.

While the simulation results (seen on pages 110-113 of the report) do show slab floors to exhibit very low influence on heating or cooling, no cases examined the possible impact of carpet. Most similar were the $4 \mathrm{ft}$ of horizontal R-5 insulation on the interior of the slab, but these cases showed increases to cooling in the Miami climate and no help with heating-which were contrary to what was measured in our experiments. However, it can be argued that carpeted floors are quite different to what was simulated in the Building Foundation Handbook research. Still, this suggests caution in applying even detailed finite difference models and the importance of having empirical data with which to examine their predicted influences.

The FRTF measurements also contradict the BEopt foundation model using the Winkelmann (2002) approximations within EnergyPlus. While the savings of carpeted floors on heating was not shown by simulation (which was actually observed), the simulation-predicted savings for cooling from tiled floors was not seen. It is worth noting that the same limitation existed with other software often used for residential analysis. For instance, EnergyGauge USA software showed the same errant behavior as BEopt; not surprising as it also uses the Winkelmann foundation model as linked with DOE-2.1E software.

None of the monitored performance showed the advantage for cooling that the EnergyPlus within BEopt and or DOE-2 simulations tended to indicate was available from uncarpeted tile floors. This becomes a significant finding with some need to critically examine the underlying foundation simulation models and how they compute heat loss and gain. The Winkelmann (2002) correlations are often used with DOE-2 and its implementations, but there is some evidence that these may misrepresent earth contact thermal loads.

As an illustrative exercise, we input a building with very similar characteristics to the FRTF test homes and then examined how carpet affected loads with a slab-on-grade floor when using EnergyPlus for the calculations. The Melbourne, Florida, TMY3 data was used for the simulation with heating and cooling set points chosen to approximate the control conditions: $73^{\circ} \mathrm{F}$ and $77^{\circ} \mathrm{F}$, respectively. 


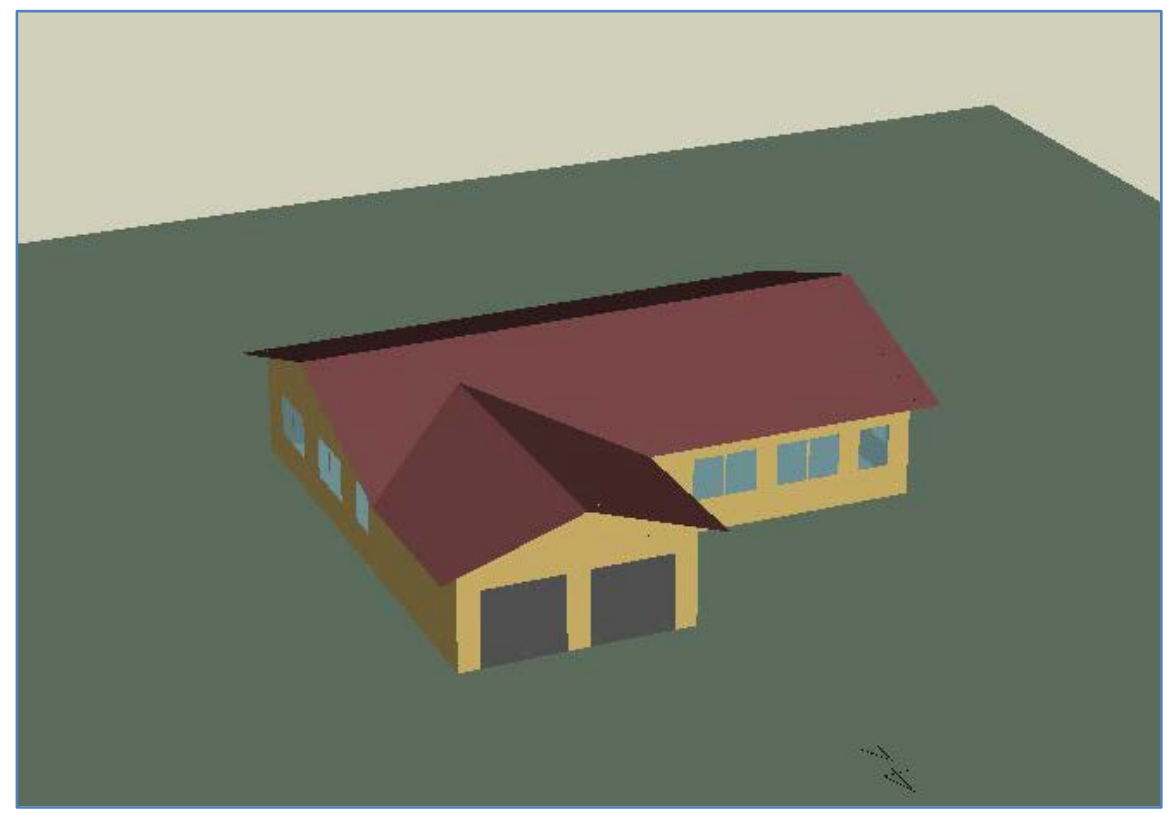

Figure 26. FRTF geometry input into BEopt with EnergyPlus

Unfortunately, the BEopt estimates contradicted the measured results, both for cooling and heating (Figure 27). The EnergyPlus simulation suggested that compressor cooling energy would be increased by $6 \%$ by having a floor covered by $100 \%$ carpet whereas the experimental measurements above suggested a small $(1 \%-2 \%)$ decrease over the full cooling season. Moreover, the simulation estimated a $100 \%$ carpeted floor would use $539 \mathrm{kWh}$ for heating over the year against $440 \mathrm{kWh}$ for a totally tiled floor. Although a modest difference in terms of annual energy, this is a $22 \%$ difference in the opposite direction to the measured results which suggested a $4 \%$ reduction in space heating for a carpeted floor for heating versus an unsurfaced slab. Further exploration at other set points did not help resolve the disparity. Even at a cooling and heating set point of $73^{\circ} \mathrm{F}$, BEopt estimates continued to show an advantage for lower HVAC cooling energy for an uncarpeted slab floor. 


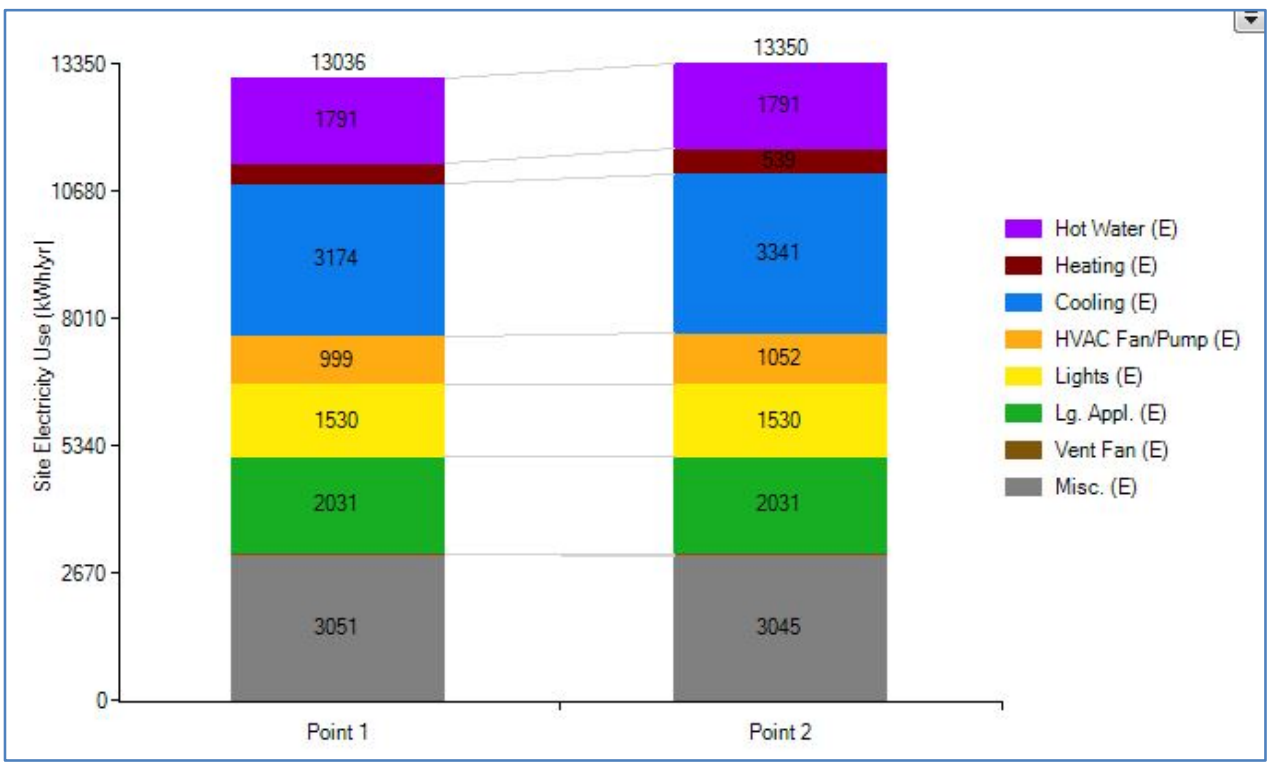

Figure 27. Simulated results for no-carpet (Point 1) versus carpet (Point 2) in FRTF with BEopt and EnergyPlus

These issues have already been identified by Andolsun et al. (2012) in comparing TRNSYS to the DOE-2 and EnergyPlus simulation where standard calculation methods were shown to exaggerate loads by $10 \%-13 \%$. However, these data should provide data that will allow further refinement of relevant models. These have a long evolution such as those by Labs et al. (1988), Bahnfleth (1989), Claesson and Hagentoft (1991), Deru (2003), and Zhong and Braun (2007).

Underlying data on soil temperature and slab profiles from the FRTF experiments at FSEC may be able to be profitably evaluated to help address the shortcomings of the current simulation models. This may allow superior calculations for future simulation models. One potentially useful task would be to compare the measured and simulated EnergyPlus surface temperatures estimated for the comparative case. ${ }^{12}$

\subsection{Sensitivity to Soil Temperature Assumptions in BEopt}

To explore whether the soil temperatures assumed were to blame for the poor correspondence between measurement and the BEopt results, we took the EnergyPlus files for the FRTF and edited the monthly ground temperature input file for the software.

The current calculations use the monitored average air temperature from 3 months prior with the Winkelmann algorithm to estimate the floor impact on heat transfer. We evaluated two variations in those temperatures, aware that the ground temperature tends to be $3^{\circ} \mathrm{F}$ to $6^{\circ} \mathrm{F}$ warmer than the air temperature due to solar irradiance and other effects. The current BEopt monthly soil temperatures for the Melbourne, Florida, TMY3 site are as follows:

\footnotetext{
${ }^{12}$ One problem could be in assuming soil surface temperature is equivalent to ambient air temperature, whereas it is often $2^{\circ} \mathrm{F}$ to $6^{\circ} \mathrm{F}$ higher because of soil surface heating from solar irradiance, resulting in higher deep-ground temperatures. For instance, the average ambient air temperature at the FRTF experimental facility for all of 2014 was $71.9^{\circ} \mathrm{F}$, whereas the deep-ground temperature was $77.6^{\circ} \mathrm{F}$. This may also be true in extreme north locations due to snow cover insulating the winter ground against heat loss.
} 


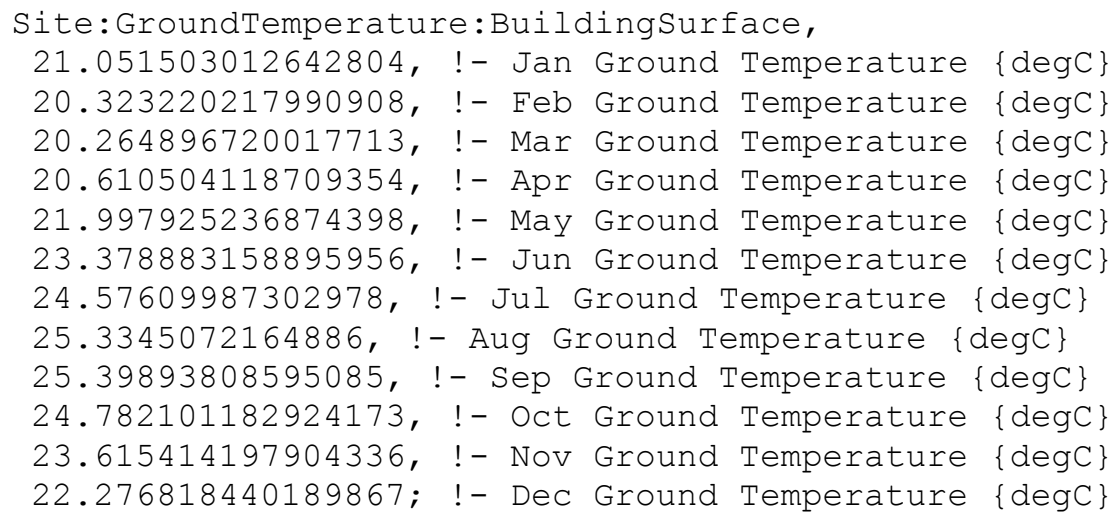

We edited the above file and then re-simulated using ground temperatures either $+3^{\circ} \mathrm{F}$ or $+6^{\circ} \mathrm{F}$. Results are shown below in annual kilowatt-hours from the revised EnergyPlus simulations for the FRTF building using Melbourne, Florida, weather and heating and cooling set points of $73^{\circ} \mathrm{F}$ and $77^{\circ} \mathrm{F}$, respectively.

\begin{tabular}{llll} 
& $\begin{array}{l}\text { Base Condition } \\
\text { Heat/Cool } k W h\end{array}$ & $\begin{array}{l}T \_g r o u n d \\
\text { Heat }+ \text { Cool } 3 W h\end{array}$ & $\begin{array}{l}T \_g r o u n d+6^{\circ} \mathrm{F} \\
\text { Heat } / \text { Cool } k W h\end{array}$ \\
\cline { 2 - 4 } No Carpet & $441 / 3174$ & $363 / 3406$ & $296 / 3645$ \\
Carpet & $538 / 3341$ & $477 / 3505$ & $424 / 3671$
\end{tabular}

Bearing in mind that monitoring showed approximately 5\% lower space heating with carpet while cooling was largely unaffected (lower in spring, more in summer without carpet), none of the above modifications were able to replicate this result. The case $\mathrm{T}$ ground $+6^{\circ} \mathrm{F}$ is closest to the observed behavior for cooling where no real advantage was seen. However, the reduction to space heating from carpet, shown in the experiment, is not shown in any of the simulation cases although, not surprisingly, foundation heat loss appear very sensitive to the monthly assumed ground temperatures. This may mean that BEopt is currently overpredicting winter heat losses for the earth contact portion of the building.

Based on the data shown for computed surface floor fluxes, we see carpet reducing winter heat loads because there are strong edge heat losses in winter that are not replicated in the simplified BEopt calculation. These edge losses take place even when the ground temperature is warm, but the temperature near the slab edge may be low due to prevailing ground-level air temperature conditions.

This exercise would indicate that simply increasing the ground temperatures in BEopt will not necessarily solve the heat-transfer phenomenon observed. A more sophisticated analytical simulation method appears to be needed. 


\section{Conclusions}

In experiments from 2014 to 2015 , we evaluated the impact of slab floors on space heating and cooling in the central Florida climate in two residential buildings instrumented in detail. The east building had standard carpet and pad over the monolithic slab, and the west building had unsurfaced exposed concrete. Both buildings were carefully configured to be otherwise nominally identical. A cooling set point of $77^{\circ} \mathrm{F}$ was used in both buildings, and a heating set point of $73^{\circ} \mathrm{F}$ was imposed. We report the following findings from the observation of the foundation experiments.

\subsection{General Findings}

The average monthly deep-ground temperature in central Florida at a 20 - $\mathrm{ft}$ depth varies by only a few degrees, from $77^{\circ} \mathrm{F}$ to $78^{\circ} \mathrm{F}$, during the year and is out of phase with the outdoor air temperature, with the minimum point in spring and the maximum in late autumn.

Evidence of bidirectional heat flow in the slab floor is shown based on the profile of temperatures varying with depth. The west building with the uncovered floor showed slightly greater amplitude in temperature variation in soil profiles beneath the building during the year. A fundamental finding is that slab floors have relatively minor thermal influence on building heating and cooling loads in central Florida's climate under the temperatures examined. In particular, they show low influence on space cooling, with the center slab floor being nearly adiabatic with the deep-ground temperature during the summer season. However, for space heating carpeted floors were shown to have small energy savings advantages compared to uncarpeted slab floors.

\subsection{Space Heating}

The carpeted slab floor appears to offer a small advantage for space heating in central Florida during days with average temperatures colder than $55^{\circ} \mathrm{F}$, with reductions of $4 \%$ to $5 \%$ more than the uncarpeted building. This fits with expectations that slab heat transfer would be reduced by carpet and pad. Losses are greatest at the slab edge.

\subsection{Transition Season between Heating and Cooling}

During the spring "shoulder" season, which has little or no heating or cooling, the uncarpeted west building floated at a temperature lower than that of the carpeted building. This may mean that unsurfaced tile floors in Florida might delay the timing when air conditioning becomes desirable in late spring/early summer.

\subsection{Space Cooling}

During the cooling season, during both modest and more intensive cooling periods, the slab floor appeared to have a very small influence on cooling. For most cooling periods, there was little to no significant energy difference. The very hottest days showed the most significant difference between cooling energy in the carpeted versus uncarpeted home, which was $2 \%$ reduced cooling for the carpeted home. No statistically significant differences were observed between the carpeted and uncarpeted buildings in terms of interior relative humidity or dew points during heating or cooling seasons. 


\subsection{Entire-Year Space-Conditioning Impact}

Evaluating the air-conditioning and space-heating energy together for the entire year from October 2, 2014, to October 1, 2015, showed average space conditioning in the carpeted east building (heating, cooling, and blower) of $15.9 \mathrm{kWh} / \mathrm{d}(5,785 \mathrm{kWh} / \mathrm{yr})$ compared to $17.2 \mathrm{kWh} / \mathrm{d}$ $(6,285 \mathrm{kWh} / \mathrm{yr})$ in the west building with the exposed slab floor. This is a measured reduction of $1.3( \pm 0.14) \mathrm{kWh} / \mathrm{d}(499 \mathrm{kWh} / \mathrm{yr})$ for a reduction of $7.6 \%$.

\subsection{Simulation Accuracy versus Measured Data}

The experimental data contradicted the BEopt simulations regarding the influence of exposed slab floors with cooling showing only very small advantages. The BEopt simulation running EnergyPlus, on the other hand, showed no advantage for heating for carpet, which was a clear influence discovered in the yearlong monitoring effort at the FRTF. This indicates questions regarding the underlying BEopt foundation simulation models for slab floors. We evaluated the mistaken assumption that monthly ground temperatures are similar to air temperatures lagged by three months. Although the lag was not investigated, data from multiple sources including this study show that ground temperatures (starting at the surface boundary condition) are higher than air temperatures by $3^{\circ} \mathrm{F}$ to $6^{\circ} \mathrm{F}$, depending on climate, solar irradiance, and snow cover. And although correcting the ground temperatures showed the observed loss of benefit of the slab for cooling in the central Florida climate, the observed edge losses in winter were not seen in the simplified model. Regardless of changes made to soil temperature, EnergyPlus as implemented in BEopt continued to incorrectly show that an uncovered slab floor in central Florida would reduce heating.

An appropriate earth contact model for BEopt needs to be carefully reevaluated in light of empirical results and other detailed numerical calculations such as simulations using TRNSYS or the Slab preprocessor from EnergyPlus. Slab is a subprogram of EnergyPlus that calculates monthly ground temperatures for slab-on-grade buildings using a three-dimensional numerical analysis. It was originally developed by Bahnfleth (1989) and modified by Clements (2004). The boundaries of the system are interior slab surface, field soil, deep-ground, and ground surface temperatures. Heat transfer is evaluated by solving node thermal performance at Cartesian coordinates using the Patankar-Spalding finite difference technique.

The three-dimensional domain of the model is discretized into a 10,000-cell grid, which makes for a very slow calculation time. Inputs are complex. The user is expected to define dimensions and grid spacing, soil and slab properties, ground surface properties, slab shape and dimensions, deep-ground temperature conditions, and even evaporative loss at ground surface, which are often unknown. The three-dimensional calculations of Slab are integrated with one-dimensional heat conduction calculations of EnergyPlus through iteration, but likely reasons that such a technique is not currently used in BEopt and similar tools include not only computational time but also difficulty in setup and specification.

Moreover, it is not entirely clear that the Slab model in EnergyPlus is a panacea to the observed discrepancy between simulated and measured influences of slab floor heat coupling. For instance, an evaluation by Andolsen et al. (2012) showed that Slab showed consistently greater reduction of cooling for slab-on-grade floor types than did the Winkelmann correlations. Also, 
there is disagreement among simulations, with a high degree of variation in estimated loads (25\% to 60\%) for slab-on-grade floor types (Neymark et al. 2009).

\subsection{Specification of Critical Simulation Inputs}

As noted by Bahnfleth (1989), proper specification of soil surface boundary conditions and even surface evapo-transpiration are critical to good simulation results. Thus, an important caution regarding our results is that they are highly sensitive to the location where the data were taken. A common error is to assume that the average annual soil surface temperature is equal to the average annual location air temperature. The average ambient air temperature at the FRTF experimental facility from July 2014 to June 2015 was $71.9^{\circ} \mathrm{F}$, whereas soil surface temperature was $74.5^{\circ} \mathrm{F}$, and the deep-ground temperature was $77.3^{\circ} \mathrm{F}$-a large difference from the ambient air temperature.

Location remains a very large factor, however. In warm central Florida where the deep-ground temperature at $20 \mathrm{ft}$ was found to be approximately $77^{\circ} \mathrm{F}$, the deep-ground thermal environment is very close to the desirable household indoor temperature. Thus, it is of little surprise that the slab floor was found to have little cooling influence during summer. Obviously results in other geographic locations would differ significantly from those seen here. Beyond climate, other important factors include soil moisture levels and water table location, although these are typically tied to local climate. Soil conditions (conductivity and diffusivity) can have large impacts (Labs et al. 1988). Finally, as shown by Spiga and Vocale (2014), building slab perimeter geometry can also modestly impact slab heat-transfer rates and characteristics among typical residential building footprint types.

The deep-ground temperature roughly follows the annual air temperature in a given location. However, it tends to be several degrees above the average annual temperature due to solar and vegetative effects on soil surface heat transfer as well as snow cover (Mount and Paetzold 2002). A climatic map of the United States reveals that conditions that are similar to those in central and south Florida prevail only in extreme southern Texas, Arizona, and California. 


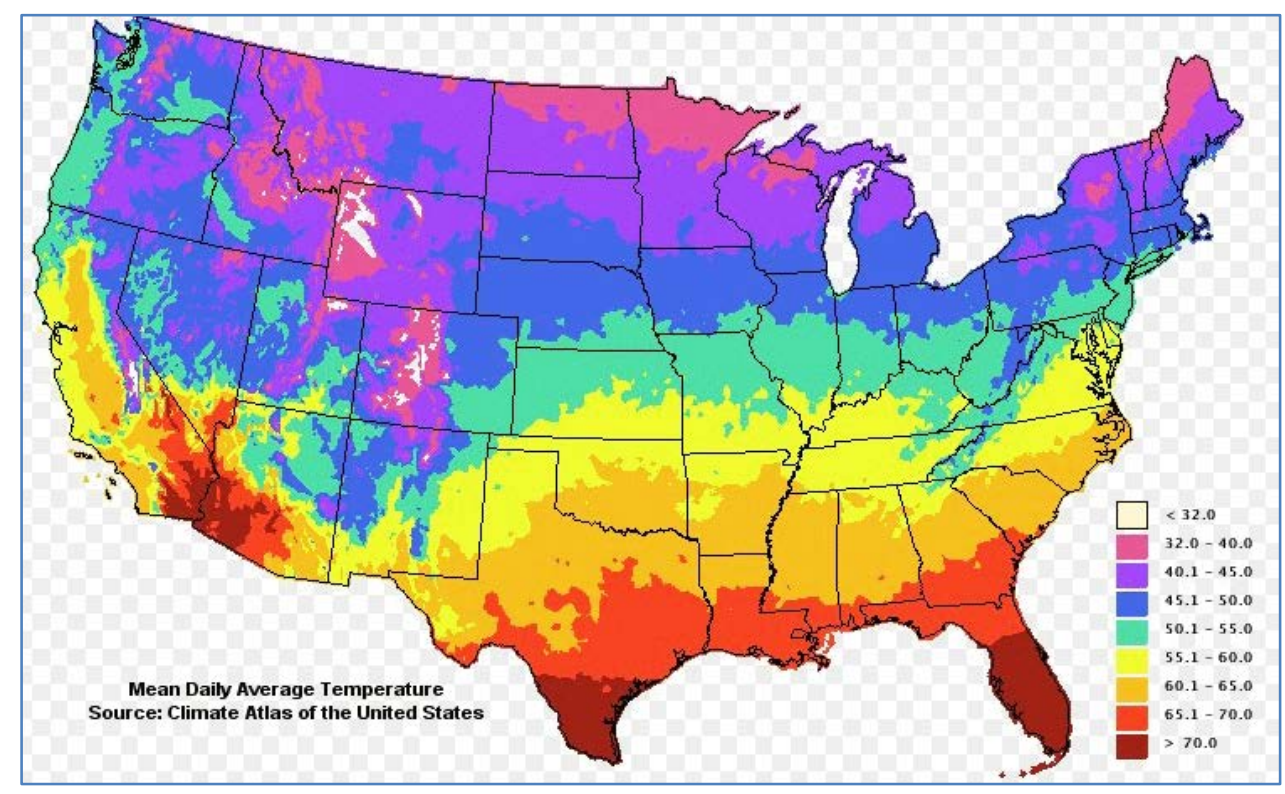

Figure 28. Map of average annual temperature in the continental United States. Image from the National Oceanic and Atmospheric Administration

Perhaps the most important caveat: Based on the results, we would expect that results would differ considerably for different interior temperature conditions. For instance, a household maintaining $80^{\circ} \mathrm{F}$ inside during the cooling season would likely see an air-conditioning advantage from the uncovered slab floor - considerably greater than what was measured herewhereas occupants maintaining $73^{\circ} \mathrm{F}$ would find the carpeted floor to yield significant performance advantages during the cooling season. 


\section{References}

Adjali, M.H., Davies, M., Rees, S.W., and Litter, J. 2000. “Temperature In and Under a Slab-OnGrade Ground Floor: Two and Three Dimensional Simulations and Comparison with Experiment Data," Building and Environment, 2000; 35:655-652.

Andolsun, S., Culp, C., Haberl, J., and Witte, M. 2012. "EnergyPlus vs DOE-2.1e: The effect of ground coupling on cooling/heating energy requirements of slab-on-grade code houses in four climates of the US," Energy and Buildings, Volume 52, September 2012, pp. 189-206.

Bahnfleth, W.P. 1989. “Three Dimensional Modeling of Heat Transfer from Slab Floors," U.S. Army Corps of Engineers, USACERL Technical Manuscript E-89/11, July 1989.

Bareither, H.D., Fleming, A.D., and Alberty, B.E. 1948. Temperature and Heat loss Characteristics of Concrete Floors Laid on the Ground. Report 48-1, Small Homes Council, University of Illinois, 1948.

Claesson, J. and Hagentoft, C.E. 1991. "Heat Loss to the Ground from a Building-I. General Theory," Building and Environment, 26(2):195-208.

Clements, E. 2004. Three Dimensional Foundation Heat Transfer Modules for Whole-Building Energy Analysis. MS Thesis, Pennsylvania State University.

Deru, M. 2003. A Model for Ground-Coupled Heat and Moisture Transfer from Buildings. NREL/TP-550-33954, National Renewable Energy Laboratory, Golden, CO. June 2003. Accessed January 18, 2016. www.nrel.gov/docs/fy03osti/33954.pdf.

Evett, J. and Liu, C. 2007. Soils and Foundations. (7th ed.), Prentice Hall, pp. 9-29, 2007.

Kusuda, T. 1967. "Least Squares Technique for the Estimation of the Periodic Temperatures of Earth's Surface Region," Journal of Research of the National Bureau of Standards, Washington, DC, Volume 71C, January-March 1967.

Kusuda, T. and Achenbach, P.R. 1965. Earth Temperature and Thermal Diffusivity at Selected Stations in the United States. Research Report 8972, National Bureau of Standards, May 1965.

Kusuda, T. and Harrington, K. 1982. "A Comparison of Ground and Above Ground Climates for Identifying Appropriate Cooling Strategies," Passive Solar Journal, Volume 1, Number 1, 1982, pp. 4-11.

Labs, K., Carmody, J., Sterling, R., Shen, L., Huang, Y.J., and Parker, D. 1988. Building Foundation Design Handbook. ORNL/Sub/86-72143/1, Oak Ridge National Laboratory, Oak Ridge, TN, May 1988. Accessed January 18, 2016. http://web.ornl.gov/sci/buildingsfoundations/handbook/toc.shtml. 
Mount, H.R. and Paetzold, R.F. 2002. The Temperature Regime for Selected Soils in the United States. Soil Survey Investigations Report No. 48, U.S. Department of Agriculture, Natural Resources Conservation Service, National Soil Survey Center, Lincoln, NE, 2002. Accessed January 18 , 2016. http://www.nrcs.usda.gov/Internet/FSE_DOCUMENTS/nrcs142p2_051004.pdf.

Neymark, J., Judkoff, R., Beausoleil-Morrison, I., Ben-Naki, A., Crowley, M., Deru, M., Henninger, R., Ribberrink, H., Thorton, J., Wijsman, A., and Witte, M. 2009. “IEA BESTTEST In-Depth Diagnostic Cases for Ground Coupled Heat Transfer Related to Slab-on-Grade Construction," Preprint, 11th International IBPSA Conference, Glasgow, Scotland, July 27-30, 2009. Accessed January 18, 2016. http://www.nrel.gov/docs/fy09osti/45742.pdf.

Spiga, M. and Vogale, P. 2014. "Effect of Floor Geometry on Building Heat Loss via the Ground," Heat Transfer Engineering, Volume 35, Issue 18, March 4, 2014. Accessed January 18, 2016. doi:10.1080/0145³2.2014.897560.

Sutherland, K., D. Parker, E. Martin, D. Chasar, and B. Amos. 2016. Phased Retrofits in Existing Homes in Florida Phase II: Shallow-Plus retrofits. NREL/TP-550-65366, National Renewable Energy Laboratory, Golden, CO. http://www.nrel.gov/docs/fy16osti/65366.pdfVieira, R. and Sherwin, J. 2012. Flexible Residential Test Facility Instrumentation Plan. Report to the U.S. Department of Energy, Office of Energy Efficiency and Renewable Energy, Building America Building Technologies Program.

Winkelmann, F. 2002. "Underground Surfaces: How to get a Better Underground Surface Heat Transfer Calculation in DOE-2.1E," Building Energy Simulation User News, 23(6):19-26.

Zhong, Z., and Braun, J.E. 2007. "A simple method for estimating heat transfer in slab-onground floors," Building and Environment, Volume 42, Issue 3, pp. 1071-1080. Accessed January 18, 2016. doi:10.1016/j.buildenv.2005.01.030. 


\section{Appendix. Kusuda's Procedure To Estimate Soil Thermal Diffusivity}

The soil heat conduction in the semi-infinite homogeneous solid may be written as follows (Kusuda 1967):

$$
\alpha \frac{\partial^{2} t}{\partial x^{2}}=\frac{\partial t}{\partial \theta}
$$

where

$$
\begin{array}{ll}
\alpha & =\text { Thermal diffusivity } \\
\mathrm{t} & =\text { Earth temperature } \\
\mathrm{x} & =\text { Earth depth from earth surface } \\
\theta & =\text { Time }
\end{array}
$$

A possible solution of monthly average soil temperature for the above heat conduction equation may be expressed as a function of depth:

$$
t=A(x)-\sum_{i=1}^{\infty} B_{i}(x) \cos \left(\omega \theta-P_{i}(x)\right)
$$

where

$\mathrm{t}=$ Calculated monthly average soil temperature

$\mathrm{A}(\mathrm{x}) \quad=$ Annual average soil temperature at a given $\mathrm{x}$

$\left.\mathrm{B}_{\mathrm{i}} \mathrm{x}\right)=$ Amplitude of annual cycle of the monthly average soil temperature at a given point $\mathrm{x}$

$$
B_{i}(x)=G_{i} * \exp \left(-\sqrt{\frac{i \pi}{\alpha T}} x\right)
$$

$\mathrm{P}_{\mathrm{i}}(\mathrm{x})=$ Phase angle of the soil temperature cycle for a given $\mathrm{x}$

$\mathrm{T} \quad=$ Period of cyclic data

$$
P_{i}(x)=\Phi_{i}-\sqrt{\frac{i \pi}{\alpha T}} x
$$

In order to simplify the solution, the first harmonic item is used and any higher order harmonics are ignored. The simplified solution may be written as:

$$
t=A(x)-B_{1}(x) \cos \left(\omega \theta-P_{1}(x)\right)
$$

The thermal diffusivity $\alpha$ can be readily calculated by knowing $\mathrm{B}_{1}(\mathrm{x})$ and $\mathrm{P}_{1}(\mathrm{x})$ at two different depths $\mathrm{x}_{1}$ and $\mathrm{x}_{2}$ by the following formulas: 


$$
\alpha_{B_{1}}=\frac{\pi}{T}\left[\frac{x_{1}-x_{2}}{\log \left(\frac{B_{1}\left(x_{2}\right)}{B_{1}\left(x_{1}\right)}\right)}\right]^{2}
$$

and

$$
\alpha_{P_{1}}=\frac{\pi}{T}\left[\frac{x_{1}-x_{2}}{P_{1}\left(x_{1}\right)-P_{1}\left(x_{2}\right)}\right]^{2}
$$

It should be pointed out that the diffusivities calculated by amplitudes (B) and phase angles (P) may be different significantly. Fortunately, the present calculations using amplitudes and phase angels are compatible. 


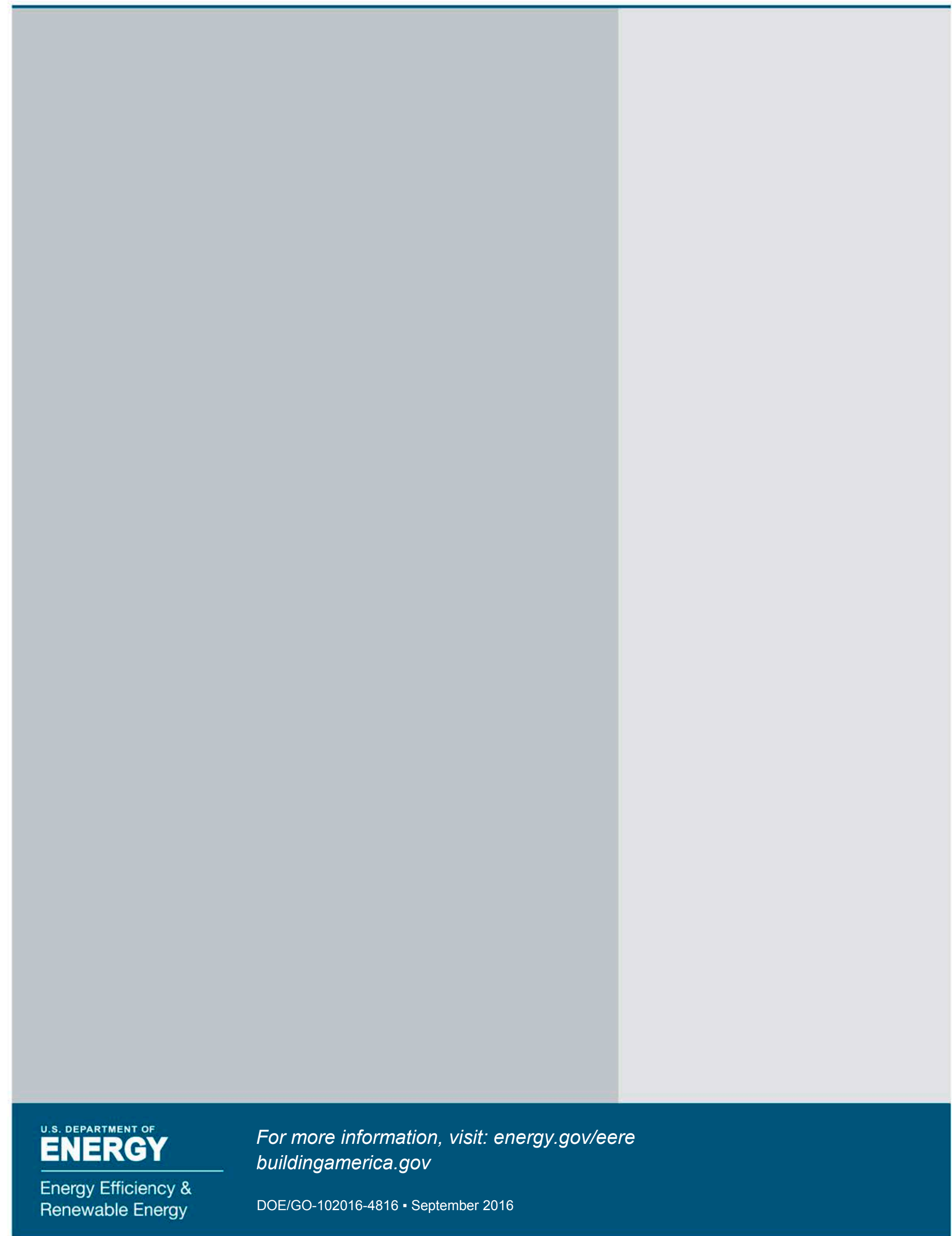

